\title{
The many faces of Reigate Stone: an assessment of variability in historic masonry based on Medieval London's principal freestone
}

\author{
Martin Michette ${ }^{1 *}\left(\mathbb{0}\right.$, Heather Viles ${ }^{1}$, Constantina Vlachou ${ }^{2}$ and lan Angus $^{3}$
}

\begin{abstract}
Reigate Stone was used in high profile projects across London during a key growth period and represents an important chapter of architectural heritage. Historic Reigate masonry is subject to inherent variability. It is prone to rapid decay; however, highly decayed and well-preserved stones are frequently adjacent. This inherent variability in masonry can present a challenge to the design of conservation strategies by obscuring or complicating the identification of decay processes. This paper presents a model for assessing the combined impact of construction economies and mineralogical variability (Graphical abstract), by synthesising archival research on the history of Reigate Stone with experimental analysis of its properties. The limitations of the local geography coupled with the demands of the medieval building industry are shown to have introduced inherent variability into the built fabric at an early stage. Later socio-economic factors are shown to have compounded these by contributing to selective recycling, replacement and contamination of Reigate Stone. These historic factors augmented pre-existing mineralogical variability. This variability makes classification according to commonly used stone types difficult. Experimental analysis correlates variable cementing components with hygro-physical properties related to resilience. Calcite content influences strength properties and capillarity; clay content influences moisture adsorption and retention; opal-CT forms a weakly cemented, porous matrix. These presented different decay pathways to a range of environmental mechanisms and agents of decay. The findings suggest that inherent mineralogical variability, environmental changes, and historic contingency must all be considered in the design of ongoing Reigate Stone conservation strategies.
\end{abstract}

Keywords: Cultural heritage, Historic architecture, Stone decay, Construction economics, Lithological variation

\section{Introduction}

Reigate Stone was used as a freestone across southeast England from the eleventh until the sixteenth century, contributing significantly to the re-emergence of masonry architecture in Britain during this period [1]. Freestones are stones used for ashlar and ornamental masonry. Suitable lithologies can be cut freely in any direction and worked easily with a chisel; they tend to be fine-grained, soft and homogeneous. Whilst this makes them easy to sculpt, it can also make them prone to

\footnotetext{
${ }^{*}$ Correspondence: martin.michette@ouce.ox.ac.uk

${ }^{1}$ School of Geography and the Environment, University of Oxford, Oxford, UK

Full list of author information is available at the end of the article
}

rapid decay. Many architecturally important regions have inherited a legacy of vulnerable historic masonry due to the nature of their principal freestone; such as Tuffeau in central France, Lede Stone in Belgium and Opuka in Prague [2-4]. Other examples exist in England, such as Clunch and Headington Stone [5, 6]. Given the historical information stored in regional building stones and the aesthetic contribution of ornamental masonry, the decay of these valuable freestones impacts significantly on the deterioration of architectural heritage.

Reigate Stone masonry displays a wide range of conditions, varying in pattern, rate and state of decay. These are frequently visible within single masonry units (Fig. 1). Historically, it was widely replaced due to rapid decay, initially with fresh Reigate Stone and later with alternative 


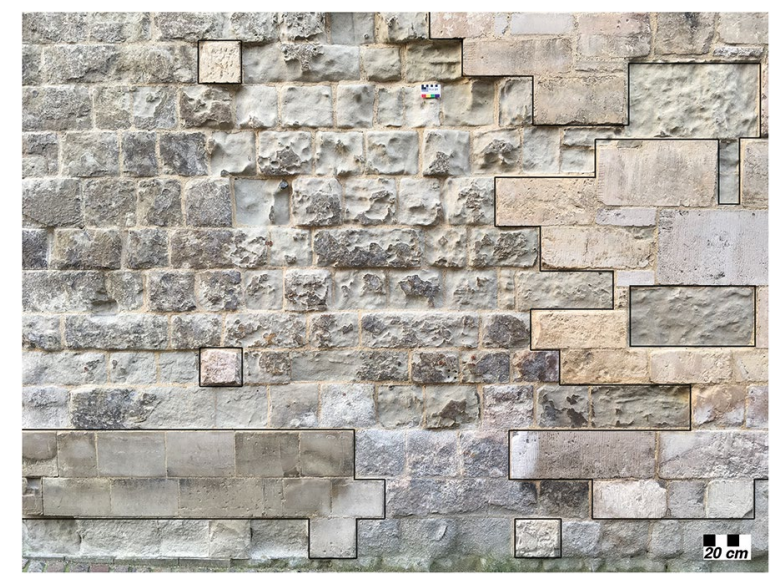

Fig. 1 Reigate Stone masonry at the Bell Tower, Tower of London, showing high level of variability. Majority of masonry is in Reigate Stone, with range of block colours and sizes, and decay patterns and rates. Second and third course are replaced with other lithologies (except central stones); approximately 15 stones on right of picture also replacement lithologies. Boundary between Reigate and other stone marked by black border

lithologies [7]. However, there are examples of primary Reigate masonry which has survived in relatively exposed locations, such as the base of the White Tower, for almost 1000 years. Since replacement gave way to conservation in the mid-twentieth century, there has been persistent uncertainty regarding the relative role of stone petrology and environmental mechanisms in decay processes [8]. There have been attempts to associate exposure with patterns and rates of decay. These have failed to account for the full variability evident in historic masonry. There has been little consideration of the role historic contingency can play in long-term decay processes; the cumulative effect of past context, be it factors pertaining to the initial construction, environmental exposure, or remedial treatment of masonry. Several attempts at conservation have accelerated decay. In order to more fully understand the deterioration of Reigate Stone, and design appropriate conservation strategies, it is necessary to understand the variable decay found within historic masonry.

Several factors are likely to contribute to differential decay in masonry construction.

- Differences in petrology result in different resistance to decay. These arise from mineralogical variability and physical characteristics such as porosity. Petrographic variability is not restricted to different lithologies; there can be considerable variation across the facies of a single geological formation [9].

- Differences in workmanship, seasoning or laying can amplify petrographic variation.
- Seasoning is an important process in calcareous freestones [10 p. 15-17]. It involves the case hardening of the stone following its extraction, as moisture from within the pore matrix migrates to the surface, a process which could take several years. Its importance has long been noted in stone conservation practice, but it has received little scientific attention. Case hardening has been noted in Reigate Stone [11, 12 p. 420]; stone was sometimes stored within the mines for seasoning (Fig. 2e) [13].

- The orientation of stones laid within masonry can greatly impact their resistance to decay due to anisotropy [14 p. 52-53]. Anisotropy is an expression of heterogeneity in a stone. It is present in many sedimentary rocks due to bedding. The compressive strength tends to be highest in the direction of bedding [15]. It also affects capillarity. Incorrect bedding is not uncommon, particularly in stones where bedding planes are difficult to determine.

- Once within the building, material variations can be compounded by micro-climatic variations at the stone-environment interface, and once decay patterns emerge within a masonry system, non-linear dynamics can amplify any initial differences [16]. Frequent changes to the micro- or macro-environment are likely over the long life-span of a building, for example due to the removal of nearby shelter or a reduction in atmospheric pollution. Past environments can have ongoing effect on stone decay [17].

- Finally, repair of the masonry, including selective replacement or treatment of deteriorated stones and mortar, will alter existing properties and introduce new variability, whilst frequently obscuring evidence of past variability [6].

The cumulative effect of these factors upon historic masonry can be complex compositions of individual stones bearing unique mineralogical, chemical and environmental signatures.

Studies of Reigate Stone have focussed either on its conservation [e.g. 7, 8, 18] or an assessment of its quarrying and use in architecture [e.g. 1, 13, 19, 20]. These valuable contributions have highlighted mineralogical features and decay processes, or provided detailed historical analysis, which can explain specific differences in Reigate Stone, but have not formed a combined approach which can adequately describe the cumulative effect of processes contributing to variability in historic masonry. As part of a wider project on understanding Reigate Stone decay at the Tower of London, this paper aims to build a hypothetical, general model of these processes. 

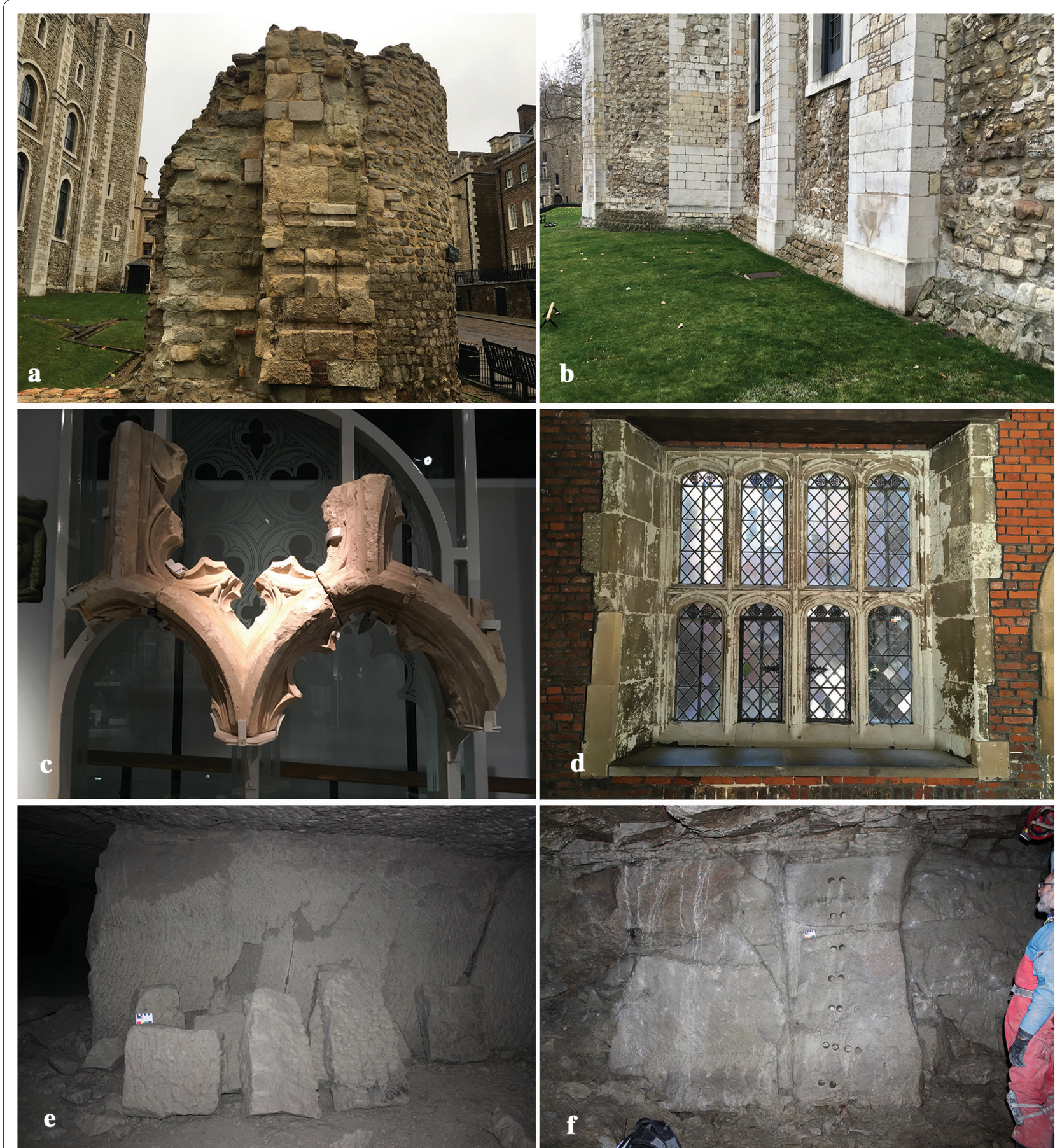

Fig. 2 a Twelth century Wardrobe Tower, Tower of London, showing decayed, south facing Reigate Stone ashlar in upper part of buttress and to left of buttress. $\mathbf{b}$ Eleventh century White Tower, Tower of London with east facing Reigate Stone ashlar visible in two courses directly above batter, and predominantly Portland Stone replacements. c Reigate Stone tracery from eleventh century Merton Priory on display in Museum of London. $\mathbf{d}$ Reigate Stone tracery in sixteenth century north cloister of Hampton Court Palace. e Large blocks of stone left in quarry near Chaldon (scale card is $8 \mathrm{~cm}$ across). f Quarry face near Merstham from which samples were extracted in 1998

Building a model of the processes which have contributed to variability in historic masonry can improve the understanding of stone decay in general and identify controls for ongoing conservation strategies. The purpose of this paper is to investigate the role of Reigate Stone variability in predetermining the emergence of 
differential decay. The investigation will synthesise historical analysis of Reigate Stone economics with experimental analysis of its material properties. This combined approach is vital for establishing a complete picture of historic building materials. Synthesising detailed historical analysis can also help to overcome some common problems in the field of historic building material analysis, such as limited access to samples. The objectives are to establish a timeline of Reigate Stone exploitation which can identify patterns of use and factors pertaining to inherent variability within masonry systems, define variability in mineralogical terms, and link mineralogical composition to physical characteristics known to influence decay. This will facilitate ongoing identification of the specific mechanisms which drive the decay of vulnerable masonry. It is also intended to contribute to persistent debate on the correct lithological definition for Reigate Stone [8]. The overall aim is to inform a methodological framework for evaluating architectural heritage under severe threat.

\section{Historical analysis Geological context}

Reigate Stone was quarried from a thin band of Upper Greensand in northern Surrey. The Upper Greensand is a Cretaceous deposit of lenticular masses formed in shallow sea conditions, which extends across southern England [12]. Upper Greensand lithologies are characterised by fine-grained silicate minerals and green, clay mineral bearing glauconite; however, an unstable paleogeography with changes in sea level, climate and faunal deposition has resulted in a complex geology with inherent variability at macro- and micro-scales [21, 22]. The facies exploited for Reigate Stone consist of intercalated lenses of varying hardness and homogeneity [23p. 84-91]. Early characterisations of the building stone noted roughly equal proportions of silica and calcium carbonate [24, 25 p. 9]. Whilst it has been referred to as both a siliceous limestone and more commonly a calcareous sandstone, Sanderson and Garner [8] state it cannot truly be classified as either. Its dominant mineral phase is opal-CT, precipitated crystalline silica which forms both a highly micro-porous matrix and functions as the main cement of very fine-grained quartz and bioclastic components.

The Reigate Stone industry saw the development of a vast network of mines, running approximately $15 \mathrm{~km}$ from Godstone in the East to Brockham in the West (Fig. 3) and exploited for several purposes [19]. This has led to terminological and lithological ambiguities. In medieval times Reigate Stone and spelling variations thereof were already being used as superordinate terms for stones from nearby areas, such as Merstham. Despite this, specific references to Merstham Stone and Chaldon Stone are not uncommon. Whilst these may refer to individual quarries or workings, there is no indication that they implied a difference in quality or function.

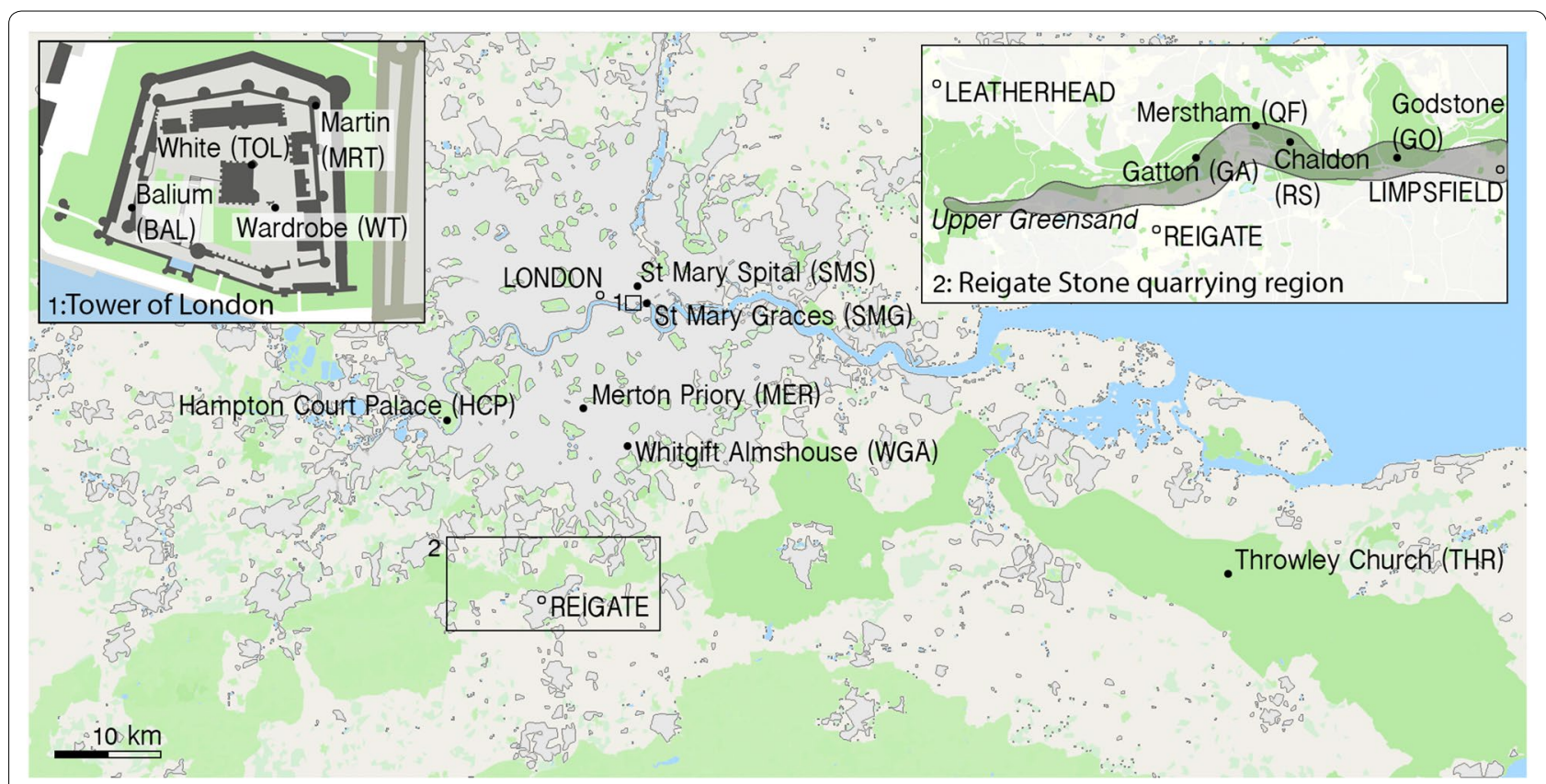

Fig. 3 Map of area around Reigate and London, showing (1) sampling locations in Tower of London, (2) sampled quarries and location of Upper Greensand in North Surrey, and (main map) other sampling locations along with coding system used for samples 
References to Greensand or green Sandstone may indicate Reigate Stone usage; however, a range of Upper and Lower Greensand lithologies were used as building stones [26]. The terms Firestone and Hearthstone relate to eighteenth and nineteenth century industrial uses; Firestone was used for lining ovens, Hearthstone for cleaning (i.e. whitening) doorsteps and other stone surfaces. There is some ongoing confusion as to whether they are distinct lithological varieties and if so, what their defining characteristics are. Jukes-Brown [12 p. 97] distinguishes Firestone and Hearthstone beds within the geological stratum, however their order is reversed within some mines [20]. Several sources identify Firestone as being more calcareous, comparable to stone used in buildings, and Hearthstone as being far softer and more friable $[8,23]$. Other sources claim that Firestone is more siliceous, and Hearthstone contained more calcite, lending it its whitening properties [12 p. 93, 26]. Records of Greensand and Firestone in archaeological or architectural texts relating to London are in most cases likely to indicate Reigate Stone, particularly when prefixed by Surrey [27]. Reigate Stone should be considered as a descriptive term rather than a fixed material classification; other names may persist in contemporary literature and references thereto are included in this study, yet Reigate Stone is by far the most common name for building stone from the North Surrey Upper Greensand.

Past studies of Reigate Stone used within buildings have noted high lithological variability, even within single buildings or sites. During excavations at the fourteenth century abbey St Mary Graces, built beside the Tower of London in East Smithfield, three different types of Reigate Stone were identified [ 28 p. 87]. These include a dense variety associated with the earliest phase of construction in the $1350 \mathrm{~s}$ and a softer variety used in the main phase of construction. Excavations at St. Mary Spital, built in the late twelfth and early thirteenth century, found two distinct typologies of Reigate Stone [29 p. 186195]. Variations in mineralogy, including glauconite colour and morphology and the nature of microfossils were identified [30]. The study concluded that several sources must have been used during construction. Attempts to determine precise provenance or link to building phases proved inconclusive. Sanderson and Garner [8] analysed Reigate Stone from several different quarries and buildings ranging from the Medieval to the Victorian periods and found significant mineralogical variation across samples. They suggested that calcite content was a determining factor in building stone quality.

\section{Reigate Stone building economics Roman use}

There is clear evidence that Reigate Stone was used in Roman times. Archaeological excavations in Southwark have yielded the earliest confirmed use of the stone in building, with potential first century use documented at two sites [31, 32]. Second or third century use at a funerary site in Southwark has been linked to a temple [33 p. 9-10]. There are indications that Reigate Stone was used in bastions and barracks along the city wall, with some references to 'green sandstone' made during excavation of the Roman fabric [e.g. 10 p. 31, 33 vol. 3 p. 103]. Several Roman sites near Reigate are documented as having walls built of 'local Greensand' [34], including a villa in Titsey 'partly built of sandstone (...) probably quarried on Limpsfield Common, $15 \mathrm{~km}$ to the east of Reigate [35] (Fig. 3). Several sculptures found in Southwark and Ashtead and dating back to the late-first century have been identified as Reigate Stone [36]. A tile kiln possibly dating to the late-first century and discovered near Reigate represents the earliest known use of the stone in large, squared blocks [37]. The tilery produced ceramics found at multiple sites across London and Kent [e.g. 33 p. 60, 38 p. 107]. Even if Reigate Stone was not widely used in pre-medieval masonry architecture, there is enough evidence of quarrying, artistic and industrial use to indicate it played an important role in the Romano-British economy of South-East England.

\section{Medieval London's expansion}

Ongoing, large-scale use of the stone coincides with the re-emergence of masonry architecture in the eleventh century. There is some evidence of earlier Anglo-Saxon quarrying and usage. 'Local firestone' was used in parish churches at Stoke D'Abernon and Fetcham [39 p. 14-15], with the large, walled-in lintel at St Mary's in Stoke D'Abernon suggestive of local quarrying in the late-seventh or early-eighth century [40]. Reigate Stone was used in large quantities in the mid-eleventh century construction of churches in Westminster and Waltham [41, 42]. Following the conquest, Norman masons came to regard Reigate as a local alternative to Caen Stone, although the latter was still favoured for some time. Primary Reigate ashlar can be found in the lowest courses of the White Tower (Fig. 2), indicating use during the first building phase (1066-1078) [43 p. 54-56]. This suggests existing stockpiles or supply-chains were exploited immediately after the conquest. The Domesday Book (1086) refers to two stone quarries in Surrey, which are likely to have included the Limpsfield Common site that may have been used in Roman times, but do not mention locations closer to Reigate itself [13 p. 11, 44]. Robbing of existing building stock should also be considered, especially in the 
form of the Roman city wall adjacent to the White Tower. Reigate Stone was used in detailed work for the interior of the White Tower, where its location corresponds with the building break in the $1080 \mathrm{~s}$. Whilst precise reasons for the break remain unclear, it is notable that courses of Reigate interspace the use of Caen Stone [43 p. 104-105]. This may reflect complications in supply chains from northern France. Use in this period, with masonry construction limited to a few key buildings, suggests that knowledge of the stone had persisted and some degree of industry in the Reigate area was able to respond to fluctuating demand.

From the mid-twelfth century onwards the use of Reigate Stone became more prevalent [ $45 \mathrm{vol} .4 \mathrm{p}$. xxiv]. It was chosen for detailed masonry in the construction of the priories and abbeys emerging across the city, but use is also documented in secular buildings [46 p. 220 , 47,48 p. 58-59]. Starting in the $1170 \mathrm{~s}$, it was used in the construction of two bridges crossing the Thames, at Kingston and further downstream at the first stone-built London Bridge [25 p. 67, 27, 48 p. 135]. The loss of the French possessions in 1206 is likely to have limited the ongoing use of Caen Stone. The first half of the thirteenth century sees the establishment of several new quarries around Reigate and stockpiling sites along the Thames $[1$, 13 p. 17]. This expanding market is reflected in accounts for building works, with four different sources providing Reigate Stone for the construction of Westminster Abbey in the 1250s [45]. Reigate Stone from various sources continued to arrive at Westminster for over 300 years; it appears that no single quarry consistently provided stone for more than 4-5 years and accounts suggest material was frequently sourced from stockpiles rather than directly from quarries [49]. In other cases, individual quarries can be more closely associated with specific sites or buildings. A 1218 quarrying grant for land near Reigate to the canons of Waltham Abbey, the site of the eleventh century church, suggests long standing relationships between the mining parishes and their clients [1]. It also reveals an ongoing need for fresh stone at large sites, possibly in relation to early repair work. Another quarry was opened in 1241 solely to provide stone for the Tower of London [50 vol. 4 p. 271]. This coincides with a major expansion of the site's defensive capabilities, including the construction of several towers along the inner wall [45 vol. 5 p. 75]. During this period of intense building, demand may have outstripped the supply of wellsourced, well-seasoned Reigate Stone.

There are signs that the industry had largely centralised by the fourteenth century. Templates for mouldings at Westminster Palace were being sent to the Reigate quarries so that the stone could be roughly worked on the spot [51 p. 21-22]. Individual families took ownership of several quarries; the Prophete family managed quarries supplying Royal Works for over 100 years [51 p. 130]. Increased output from Merstham and Chaldon quarries in this period has been linked to an exhaustion of beds closer to Reigate [13 p. 44].

\section{Repair, recycling and replacement}

There is evidence that by the fifteenth century certain limitations to Reigate Stone were well understood and large-scale repair programs were underway. Royal accounts for the late fourteenth century make specific reference to Reigate Stone intended for repair work [52 vol. 2 p. 1008]. In some fourteenth and fifteenth century buildings, architectural details evolve to protect exposed Reigate masonry [47 p. 138, 53]; in others, the exposure of Reigate Stone to damp is avoided entirely [ 51 p. 527 , 54 p. 20, 55 p. 19]. Significant restoration activity on Reigate masonry at Westminster Abbey took place in the fourteenth and fifteenth centuries [56 p. 219-227]. This included extensive repairs to the lower south transept in 1457-1461, 200 years after its construction in Reigate Stone [ 49 p. 27]. In the sixteenth century, use of Reigate Stone as ashlar is predominantly restricted to sheltered areas; demand is likely to have drastically fallen. In an indication of declining quarrying activity, the earliest working faces in the re-opened mines around Reigate can be dated to the sixteenth century [13].

A decline in use and any apparent decline in quarrying activity should be considered within the socio-economic context of late Medieval and Tudor London. The Black Death changed the dynamic of London's urban expansion in the mid-fourteenth century [57] and impacted labour markets for two centuries. Economic recovery coincided with the dissolution of the monasteries in the $1530 \mathrm{~s}$, which provided salvageable material to fuel a renaissance in masonry architecture. Whilst it had long been used as flooring material in the form of large slabs, Tudor floors also used crushed Reigate, which may represent demolition material $[48$ p. 80, 118, 136]. The majority of Reigate Stone for Nonsuch Place (1538) came from the demolition of Merton Priory; 3643 loads of stone were sourced from Merton and only 96 loads directly from Reigate quarries [52 vol. 3 p. 184]. The re-use of building material was a common medieval practice; materials used in royal works were frequently recycled elsewhere within the royal estate. After the royal residence at Sheen (now Richmond) was demolished in the 1390s, accounts show the reuse of materials at other buildings, including the Tower of London and a new manor built in Sutton, Surrey. Large quantities of Reigate used at Sutton then found their way back to Sheen when the former was demolished after only 20 years and the latter was rebuilt [52 vol. 2 p. 998-1004]. Widespread recycling of building stone 
is likely to have occurred following economic downturn and recovery, resulting in a significant increase in the inherent variability of individual masonry units.

Later centuries saw a further refinement of the use of Reigate Stone and replacement with other stones. A major building phase in London began in the late-seventeenth century in response to the Great Fire and saw the introduction of new freestone, most notably Portland Stone, and further developments in brick manufacturing [54]. The medieval Reigate quarrying infrastructure would have been insufficient for the scale of rebuilding and expansion London underwent. Quarries in places such as Portland and Oxfordshire could be exploited on a much larger scale and stone could be transported via water along the coast or newly built canals [6]. Ongoing replacement of decaying Reigate masonry was now possible using these more robust stone types. Freshly quarried Reigate Stone was still used internally, and recycled stone was used as rubble infill. Despite reservations, Christopher Wren used large quantities of Reigate Stone in his rebuilding of the city's churches [20,58]. At St. Pauls, where Wren made deliberate, targeted use of several different types of stone, Reigate Stone was used as infill and for ashlar and mouldings [58, 59, p. 69-70]. Wren was particularly attentive to the sourcing, transport and sheltering of Reigate Stone; having identified a susceptibility to frost, he had sheds built to protect the stone during the winter [20]. As with the large medieval construction projects, supply came from multiple sources over the years [58], so despite this quality control, inherent variability is likely to have been built into the masonry.

Significant mining activity recommenced in the midnineteenth century [19]. This fed a growing demand for stone used in industrial processes, but also provided building stone for the rapid development of suburban Reigate and Redhill. Several mines were newly opened or vastly expanded in this period [13]. The mines at Merstham were extensively developed to provide stone used as infill in the construction of London and Waterloo bridges. There is evidence that some material used in buildings in this period was of poor quality, with the decay of several Victorian churches near Reigate progressing particularly rapidly [7]. Increasing pollution levels and the use of cementitious repair materials accelerated masonry decay $[17,60]$. It is likely that the impact was particularly severe on Reigate Stone. Simultaneously, Victorian stylistic restoration programs drove widescale replacement of deteriorated fabric at historic sites across the city, including the Tower of London [61]. Although the decline in overall stock will have drastically sharpened, it should be considered that fresh Reigate Stone may have entered the historic fabric as repair material in this period.
Replacement of decaying Reigate Stone continued until the mid-twentieth century, when conservation policy shifted to preservation. Initially little attention was paid to replacement typologies. Later work recognised not only the importance of aesthetic compatibility, but also geochemical compatibility with remaining Reigate masonry. Chilmark and Ketton limestone were widely used, however neither is entirely compatible. A wide range of different consolidants were trialled or extensively used on Reigate Stone in the late-twentieth century, often with sparse documentation and mixed success [18]. There are records of isolated replacement programmes using small quantities of available, fresh Reigate Stone in recent years. Since the closure of the last Hearthstone mines in the 1960s ongoing replacement with fresh Reigate Stone has become practically impossible; however, fresh stone was procured for a new stairwell at Westminster Abbey completed in 2018.

\section{Experimental analysis Objective}

The documentary analysis has shown that building stone economies are likely to have resulted in complex masonry systems, with selective extension, replacement, recycling and treatment of Reigate Stone masonry occurring across a period of several centuries. This will have compounded the effects of environmentally induced changes. Any inherent differences in individual stones would further augment the resulting variability; these will be investigated in the following section.

Experiments were conducted on Reigate Stone samples collected from different quarries and buildings in order to enable petrographic characterisation and investigate physical and hygric properties. Samples were selected to be representative of a broad geographical and historical range. Non-destructive techniques were favoured to allow a reuse of samples and enable calibration with field tests in ongoing work. Measured variables were subject to statistical analysis in order to determine correlations (Pearsons method and Principal Component Analysis) and identify patterns between freshly quarried stone and stones used in medieval buildings. The objective was to establish inherent variability in Reigate Stone and link this to mechanisms likely to drive decay processes.

\section{Materials and methods}

Three samples each from five quarries were selected. These make up part of a larger archive of samples gathered to facilitate research by Sanderson and Garner [8]. Quarries in Gatton, Merstham, Chaldon and Godstone were sampled (Fig. 3). The quarries make up networks of mines that have been gradually re-explored by local interest groups over the last 50 years [13]. Samples were 
extracted from a single gallery face near an entrance to each mine as $45 \mathrm{~mm}$ diameter cylinders using a diamond tipped core drill (Figs. 2f, 4). No water was used during the drilling. $50 \mathrm{~mm}$ pieces were cut from these cylinders for most characterisation tests, with some tests performed on smaller pieces taken from the same cylinder.

Samples from 10 different buildings were investigated (Figs. 2, 3). Four separate building phases at the Tower of London are represented. Five further sites were selected to approximate one building per century in Medieval South East England, although samples may be representative of repair material or later work. Samples from seven buildings were collected for Sanderson and Garner in the late 1990s [8]: two samples were taken by Historic Royal Palaces from the Tower of London; a sample from St. Mary Spital was supplied by the Museum of London archives; the other four samples were supplied by curators or archaeologists working at the individual sites. Detailed records on sampling locations were not available. Samples from three further buildings were made available by HRP during this study. Hampton Court Palace (HC) samples 1-6 were taken from material which had been buried and was rediscovered during landscaping work in 2016. Wardrobe Tower and Martin Tower samples, and $\mathrm{HC}$, were taken from material which detached from the buildings during conservation or surveying work. Samples were cut into prisms of $50 \times 50 \times 50 \mathrm{~mm}$ from suitably large parent material for most characterisation tests, with some tests performed on smaller pieces taken from the same parent. Some tests were also performed on additional, smaller samples from Hampton Court Palace and the Wardrobe Tower to examine variability within single buildings (Fig. 4). Sampling sites are listed in Table 1 along with approximate build dates and information on the samples.

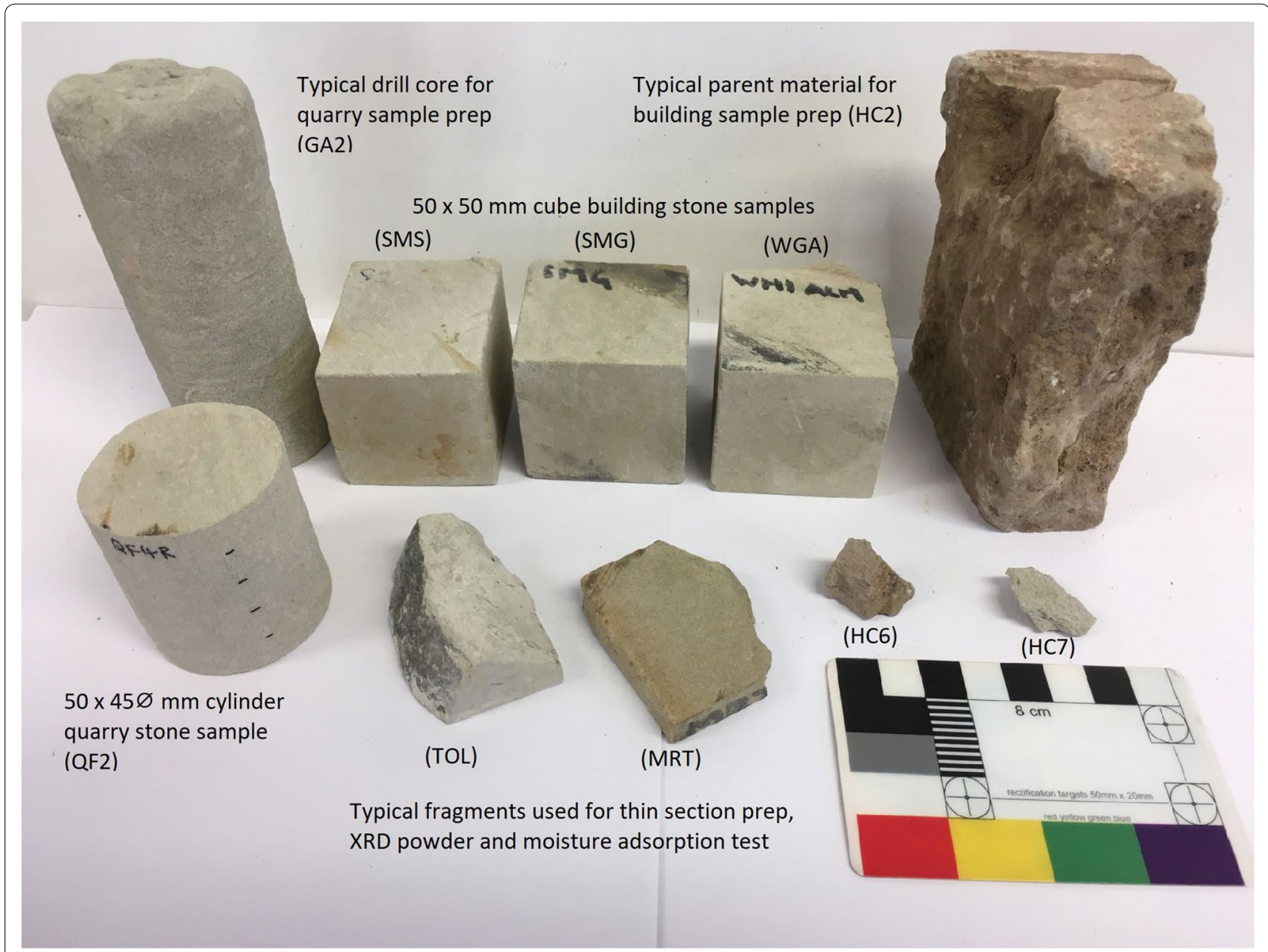

Fig. 4 Selection of Reigate Stone specimens showing variation in colour and texture across different samples used in this study and explaining different sample dimensions 
Table 1 List of quarries and buildings that provided samples for this study, with approximate date of construction/ quarrying, coding system, and information on shape, size and location of samples

\begin{tabular}{|c|c|c|c|c|}
\hline Building/Quarry & Date & Sample code & Sample size & Sample location info \\
\hline \multirow{3}{*}{$\begin{array}{l}\text { Rockshaw Lodge Quarry, } \\
\text { Chaldon }\end{array}$} & \multirow[t]{3}{*}{ Medieval to nineteenth century } & RS1 & \multirow[t]{3}{*}{ Cylinders $45 \mathrm{~mm} \varnothing 50 \mathrm{~mm} \mathrm{~h}$} & \multirow{15}{*}{$\begin{array}{l}\text { All quarry samples extracted } \\
\text { from gallery faces near quarry } \\
\text { entrances in } 1998 \text { (e.g. Figure 2f). } \\
\text { Approx. } 14 \text { samples extracted } \\
\text { per quarry at different heights. } \\
\text { Numbered here from quarry ceil- } \\
\text { ing (i.e. } 3 \text { closest to floor). Precise } \\
\text { locations known }\end{array}$} \\
\hline & & RS2 & & \\
\hline & & RS3 & & \\
\hline \multirow[t]{3}{*}{ Quarry Dean, Merstham } & \multirow[t]{3}{*}{ Medieval to nineteenth century } & QD1 & \multirow[t]{3}{*}{ Cylinders $45 \mathrm{~mm} \varnothing 50 \mathrm{~mm} \mathrm{~h}$} & \\
\hline & & QD2 & & \\
\hline & & QD3 & & \\
\hline \multirow[t]{3}{*}{ Gatton Quarry } & \multirow[t]{3}{*}{ Medieval? to nineteenth century } & GA1 & \multirow[t]{3}{*}{ Cylinders $45 \mathrm{~mm} \varnothing 50 \mathrm{~mm} \mathrm{~h}$} & \\
\hline & & GA2 & & \\
\hline & & GA3 & & \\
\hline \multirow[t]{3}{*}{ Godstone Quarry } & \multirow{3}{*}{$\begin{array}{l}\text { seventeenth to twentieth } \\
\text { century }\end{array}$} & GO1 & \multirow[t]{3}{*}{ Cylinders $45 \mathrm{~mm} \varnothing 50 \mathrm{~mm} \mathrm{~h}$} & \\
\hline & & $\mathrm{GO} 2$ & & \\
\hline & & GO3 & & \\
\hline \multirow[t]{3}{*}{ Quarry Field, Merstham } & \multirow[t]{3}{*}{ Nineteenth century } & QF1 & \multirow[t]{3}{*}{ Cylinders $45 \mathrm{~mm} \varnothing 50 \mathrm{~mm} \mathrm{~h}$} & \\
\hline & & QF2 & & \\
\hline & & QF3 & & \\
\hline White Tower, Tower of London & 1070 & TOL & Cube $50 \mathrm{~mm}$ & $\begin{array}{l}\text { Sample removed in 2000. Location } \\
\text { unknown }\end{array}$ \\
\hline \multirow[t]{3}{*}{ Wardrobe Tower, ToL } & \multirow[t]{3}{*}{1190} & WT1 & Cube 50 mm & \multirow{3}{*}{$\begin{array}{l}\text { Detached from south facing but- } \\
\text { tress during conservation work } \\
(04.2017)\end{array}$} \\
\hline & & WT2 & Fragment & \\
\hline & & WT3 & Fragment & \\
\hline Balium Wall, ToL & Twelfth century & BAL & Cube 50 mm & Date unknown. Location unknown \\
\hline Martin Tower, ToL & Mid- thirteenth century & MRT & Cube 50 mm & $\begin{array}{l}\text { Detached from internal door } \\
\text { reveal (2015) }\end{array}$ \\
\hline Merton Priory & Early Twelfth century & MER & Cube 50 mm & Location unknown \\
\hline St Mary Spital & Early thirteenth century & SMS & Cube $50 \mathrm{~mm}$ & $\begin{array}{l}\text { Location unknown. Obtained from } \\
\text { Museum of London archive in } \\
\text { c. } 2000\end{array}$ \\
\hline St Mary Graces & Mid-fourteenth century & SMG & Cube $50 \mathrm{~mm}$ & Location unknown \\
\hline Throwley Church & Fifteenth century & THR & Cube 50 mm & $\begin{array}{l}\text { Location unknown. Marked as } \\
\text { fifteenth century material }\end{array}$ \\
\hline \multirow[t]{7}{*}{ Hampton Court Palace } & \multirow[t]{7}{*}{ Early sixteenth century } & $\mathrm{HCl}$ & Cube 50 mm & \multirow{6}{*}{$\begin{array}{l}\text { Excavated from garden in } 2016 . \\
\text { Likely to have come from win- } \\
\text { dow jambs and been buried fol- } \\
\text { lowing eighteenth or nineteenth } \\
\text { century replacements with other } \\
\text { stone types }\end{array}$} \\
\hline & & $\mathrm{HC2}$ & Cube 50 mm & \\
\hline & & $\mathrm{HC} 3$ & Fragment & \\
\hline & & $\mathrm{HC} 4$ & Fragment & \\
\hline & & HC5 & Fragment & \\
\hline & & HC6 & Fragment & \\
\hline & & $\mathrm{HC7}$ & Fragment & $\begin{array}{l}\text { Detached from external east facing } \\
\text { window jamb (2017) }\end{array}$ \\
\hline Whitgift Almshouses & Late sixteenth century & WGA & Cube 50 mm & Location unknown \\
\hline
\end{tabular}

Quarry dates from Burgess (2008)

\section{Bulk density/open porosity}

Bulk density $\rho_{b}\left(\mathrm{~g} / \mathrm{cm}^{3}\right)$ and open porosity $P_{O}$ were calculated in accordance with the standard methodology [62].

\section{Ultrasonic wave propagation}

A PUNDIT Lab (Proteq) was used to measure ultrasonic wave propagation through the samples. The pulse velocity $V p(\mathrm{~m} / \mathrm{s})$ is related to strength characteristics [63]. The standard methodology [64] was adapted, with velocity measured along each axis of a sample, in order to enable the determination of the anisotropy coefficient $\mathrm{k}$ according to the formula

$$
k=\left(\frac{V p_{\text {max }}-V p_{\text {min }}}{V p_{\text {mean }}}\right) 100
$$


where $V p_{\max }$ is the mean maximum velocity obtained along any one axis, $V p_{\min }$ is the mean minimum velocity and $V p_{\text {mean }}$ is the average of all measurements $[15,65]$.

\section{Capillary absorption}

The capillary absorption coefficient $w k\left(\mathrm{~g} / \mathrm{m}^{2} \mathrm{~s}^{0.5}\right)$ was calculated using the standard methodology [66]. Results of the ultrasonic wave propagation tests were observed in order to ensure capillary absorption was measured along comparable planes of anisotropy.

\section{Sorptivity}

To measure moisture adsorption due to atmospheric pressure, small pieces of each sample were taken from the parent material (between 2 and $10 \mathrm{~g}$ per sample depending on availability). These were oven dried, weighed and placed in a climate chamber at a constant temperature of $20 \mathrm{C}$. Relative humidity $(\mathrm{RH})$ was increased in steps until mass equilibrium $( \pm 5 \mathrm{mg})$. Sorptivity is expressed as the amount of moisture adsorbed at $95 \% \mathrm{RH}$ as a percentage of total mass of the sample. The hysteresis between adsorption and desorption at $80 \% \mathrm{RH}$ was calculated to provide a measure of moisture retention.

\section{$X$-ray diffraction $(X R D)$}

XRD was performed to identify minerals present in powdered samples. Powder samples were prepared from additional pieces of each sample taken from the parent material, mixed with acetone and deposited on a zerobackground single crystal silicon substrate. Analysis was performed using a Panalytical Empyrean Series 2 diffractometer operating at $40 \mathrm{kV}$ and $40 \mathrm{~mA}$ with a Co $\mathrm{K} \alpha$ source. Measurements were taken in the $5^{\circ}$ to $85^{\circ} 2 \theta$ range using a step size of $0.026^{\circ}$ in reflection-transmission mode. The HighScore Plus software suite was used to reduce data, and mineral identifications were based on the correspondence of $\mathrm{d}$-spacings, intensities and profiles to the International Centre for Diffraction Data Powder Diffraction File 4+ database and quantified through the reference intensity ratio method [67]. In addition to bulk mineral phase analysis, clay mineral phase analysis was performed on a selection of powder samples following decarbonation.

\section{Optical microscopy}

Thin sections of selected samples impregnated in blue resin were analysed using an Olympus BX43. Thin sections of WT, HC and MRT were prepared during this study from additional pieces of each sample taken from the parent material, all other thin sections were prepared for Sanderson and Garner [8]. Optical microscopy was performed qualitatively in order to support and corroborate findings made using other techniques.

\section{Results and discussion}

\section{Petrographic variability}

XRD reveals quartz, opal-CT, calcite and clay minerals present in all samples (Table 2). There is notable variation in the relative proportion of these minerals (Fig. 5). Feldspar was identified in most samples. Gypsum was identified in several building stone samples. Clay analysis of decarbonated samples yielded fairly amorphous and low profile peaks which suggest the presence of discrete smectite (trioctahedral smectite, glauconite and/ or montmorillonite) represented by peaks in the region of 1.513-1.519 $\AA$, and $1.507 \AA$ respectively, in addition to illite/muscovite (1.50-1.502 $\AA$ ). The presence of muscovite can account for flakes of mica seen both macroscopically and in thin section (RS1 in Fig. 6). Within the discrete smectite regions, some samples yielded peaks at or near $1.511 \AA$ which could indicate the presence of glauconite. Glauconite can refer both to a morphological form and a mineral, typically glauconitic smectite, with considerable variation from one mineral to the next $[68,69]$. Glauconite pellets generally form in semiconfinement to replace carboniferous parent material with expandable smectite minerals. The diversity of clay minerals identified therefore reflects different stages of glauconization. This is visible in different shades of green, when comparing thin sections (e.g. comparing GA1 and WT2 in Fig. 6). The distribution of clay minerals is likely to be inhomogeneous, with mica flakes and glauconite pellets representing concentrations, but dispersed porefilling cement also possible.

Optical microscopy and physical characterisation tests indicate a physical diversity beyond the fundamental mineralogical variability. Thin sections also highlight the presence of amorphous bioclastic components such as foraminifera and sponge spicules which will not have been identified by XRD (RS1 in Fig. 6). Physical differences include the definition of bedding planes, and degree to which diagenesis and bioturbation have affected this; the homogeneity of fabric; the size and sorting of grains; and the distribution and shape of porosity. The overall open porosity varies widely across samples (Fig. 7). The abundance and density of the matrix-filling, microcrystalline opal-CT appears to affect the shape and distribution of porosity, with a microporous network extending throughout all but the densest areas of this matrix and expanding in sparser areas to larger, highly connected pores in the $10^{2} \mu \mathrm{m}$ region.

Petrographic variability is likely to relate to the chemistry of sedimentary deposition, the frequency and amplitude of changes inducing diagenesis and the overall maturity of the facies. Quartz grain size and content, and glauconite abundance and saturation are all likely to increase as a result of diagenesis from native siliceous 
and calcareous bioclasts, respectively, with opal-CT representing a transition stage of the siliceous component $[70,71]$. Demonstrative of two extremes are TOL and GA2 (Table 2; Fig. 6):

- TOL is high in opal-CT and calcite and low in quartz and clay. It has an abundance of bioclastic components, sparse, olive-green glauconite pellets and very fine quartz grains in a very dense, matrix supported fabric that shows faint signs of discontinuous bedding. The relatively low open porosity is not visible in thin section other than in some near surface fissures and is likely to be almost entirely in the microporous region.

- GA2 is dominated by slightly larger quartz grains with a high clay content reflected in abundant glauconite pellets, ranging from light- to dark-green, in a grain supported fabric with sparse opal-CT and highly disturbed bedding. Calcite content is low. The open porosity is higher, and large pores are visible between individual grains.

GA2 represents a mature sample which has undergone much diagenesis, with the majority of siliceous microfauna having transformed fully to quartz via opal-CT, whilst TOL is likely to have undergone less change, with most of the silica present in opal-CT form and traces of initial faunal deposition still present. Significant variations are also present in samples extracted from the same facies, probably as a result of initial sedimentation. GA1 displays a denser, more matrix supported fabric, and is also more calcareous and less clay-bearing than GA2 (Table 2; Fig. 6). Its open porosity is comparable to TOL; however, the structure is heterogeneous and includes pore sizes similar to those in GA2. These findings serve to illustrate the relative variability in Upper Greensand beds ranges across several mineral and physical properties, and the challenges in extracting building stone of uniform composition.

\section{Selective quarrying}

Several correlations in mineralogical composition indicate selective quarrying of building stone. In quarry samples there is a good correlation between decreasing opal-CT content and increasing quartz content $(R=-0.67)$ (Fig. 5). This reflects the diagenetic transition from the former to the latter. This correlation is not present in building stones $(R=-0.15)$, where quartz content is generally lower and opal-CT content is more variable than in quarry samples. There is a good correlation between decreasing quartz content and increasing clay content in all samples $(R=-0.65)$ (Table 4$)$. The average proportion of clay minerals in building samples $(29.4 \%)$ tends to be higher than in quarry samples (19.7\%). Viewed together with the lack of correlation between quartz and opal-CT, this may reflect a process of selecting suitable building stones which tends towards reduced quartz content. This could have favoured finer grained, homogeneous, matrix-supported stone which proved easier to finely carve.

Further analysis suggests these selection criteria may have resulted in shifts in mineralogical composition across different periods of quarrying and use. Calcite content varies but the mean value is comparable in quarry samples (16.5\%) and building samples (17.7\%). Pre-thirteenth century building stones contain relatively higher proportions $(M=24 \%$, or $18.8 \%$ without TOL), particularly when considering the formation of gypsum in WT1-3 has removed soluble calcium. Thirteenth to fifteenth century samples contain lower proportions $(M=13.2 \%)$. There is a correlation between increasing calcite content and increasing opal-CT content $(R=0.58)$ (Table 3$)$, with calcium perhaps able to precipitate and carbonise more readily in stone with a more abundant micro-porous matrix. Thirteenth to fifteenth century samples contain a high proportion of clay minerals $(M=36.4 \%)$, at the expense of opal-CT/calcite (Fig. 8). Clay content in sixteenth century samples is lower $(M=27.9 \%)$, but variability is high. This may reflect further shifts in selection and use. HC2-4 have a lower than average clay content (Table 2), which could indicate refined quality control in response to the decay of earlier building stone. However, the consequent trend in this sample set is higher quartz content; calcite content is variable. Others, such as WGA, have notably high clay content and may represent a reuse of earlier material. These shifts in selection criteria can be related to the fluctuating supply and demand discussed in the previous section.

These findings should be treated with caution given the small sample set of building stones; however, they do support claims made elsewhere that building stones were selectively quarried [8]. This is reflected in a more uniform bulk density in building stone samples (Fig. 7). The mean value for $\mathrm{p}$-wave propagation is also higher in building stones $(2151 \mathrm{~m} / \mathrm{s})$ than in quarry samples $(1973 \mathrm{~m} / \mathrm{s})$. Extant building stones are characteristically denser and stronger. However, rather than a selection based on or even reflected in calcite content, observations here suggest that ease of working may have been the principal criterion. This is likely to have favoured textural homogeneity, present in stones with a more abundant matrix and/or softer, finer grains. As demand outstripped the supply of calcareous, matrix-supported stones, an increase in the proportion of clay minerals is therefore likely to have become an unintended consequence of stones supplied to buildings. 


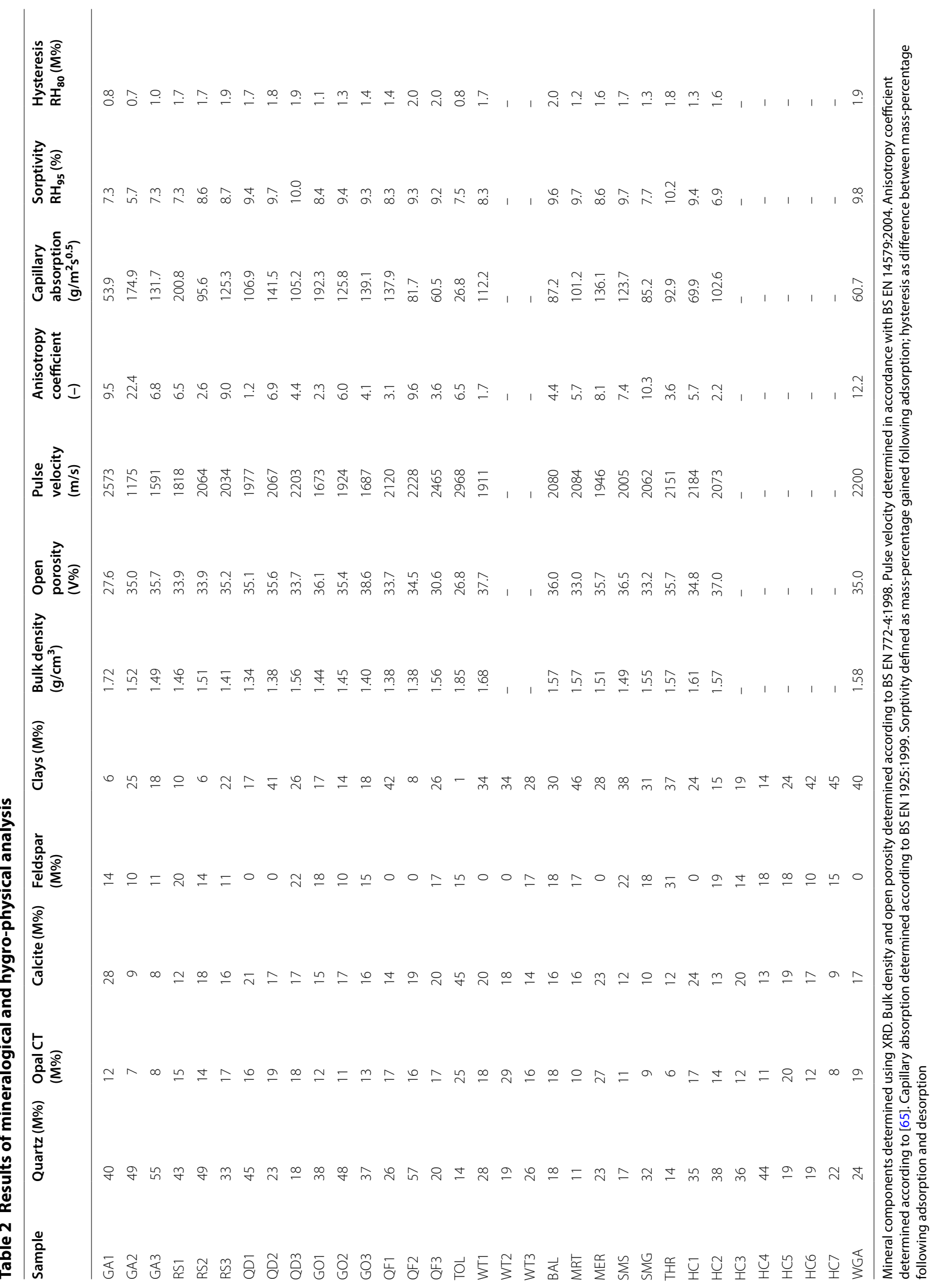




\section{Variable resilience}

In order to investigate the potential impact of variable mineralogical composition on hygro-physical characteristics, Principal component analysis (PCA) was performed. PCA is a statistical procedure to convert separate variables into linear, 'best fit' composites (called principal components (PC)), which account for the largest possible variance within a dataset [72]. The first PC accounts for as much variability in the data as possible; each succeeding $\mathrm{PC}$ has the highest variance possible whilst remaining orthogonal (uncorrelated) to its precedent. This procedure can be used to plot individual variables and samples as vectors and points in a low-dimensional data space, in order to visualise their contribution to correlated groups. It therefore provides a useful method for identifying correlations and clusters in a dataset. The facto-extra package was used in RStudio; this automatically scales and normalises data from separate variables. The analysis was performed on all samples which were tested both for mineral and hygro-physical properties, in order to explore correlations between key mineral components, strength characteristics, and hygric mechanisms. After initial runs, feldspar content, anisotropy and hysteresis were not included in order to simplify the final analysis.

Two dimensions account for almost $70 \%$ of variation (Fig. 9). These associate two mineral components with distinct hygro-physical mechanisms. PC1 groups ultrasonic wave propagation, surface hardness, water uptake and calcite content. Bulk density and effective porosity also contribute. PC1 therefore links calcite content with strength characteristics such as compressive strength, elasticity and fabric density. This indicates calcite functions as a pore clogging cement in harder, denser samples. This results in a decrease in capillarity. PC2 groups clay mineral content with moisture adsorption. The lack of any significant correlation between hygro-physical properties and opal-CT content is noteworthy, given the apparent importance of opal-CT in determining the shape of the porous matrix. However; PC3 and PC4, which each account for approximately $10 \%$ of variance, do group opal-CT content with bulk density, moisture adsorption and water uptake (Table 4). This suggests more complex interrelations, with the distribution of components throughout the matrix likely to be crucial to individual properties. These results should be treated with caution given the small number of samples and high variation within the dataset. PC1 is dominated by TOL, which accounts for $45 \%$ of the contribution. However, removing TOL from the dataset and running the PCA again results in a similar dimensionality, with $\mathrm{PC} 1$ and 2 accounting for over $60 \%$ of variability and respectively linking increased calcite content with strength and slow water uptake, and increased clay content with higher sorptivity (as well as reduced open porosity and quartz content). The correlations identified here should be viewed as patterns, which can explain Reigate Stone characteristics in terms of the relative abundance of different cementing components, and account for different rates and patterns of decay in relation to hygric mechanisms.

Reigate Stone has several characteristics which are linked to poor resilience in building stone. The mean open porosity of $34.5 \%$ is high for stones used in building [73]. Clay minerals have a low weathering resistance and can induce swelling [73]. Moisture retention of between 1 and $2 \%$ at an $\mathrm{RH}$ of $80 \%$ indicates residual moisture will be present at high atmospheric humidity and dynamic equilibrium will increase the risk of salt crystallisation cycles [74]. Whilst it is uncommon in building stones, opal-CT forms a weak, highly soluble cement [4]. However, the picture painted by the relative proportion of cementing components in relation to hygro-physical properties likely to control decay, such as strength and moisture retention, is not as clear as the PCA might suggest (Fig. 8). Beyond baseline mineralogy, lower values for $\mathrm{p}$-wave propagation in older buildings indicate more advanced decay in some samples, whilst others such as TOL appear to remain resilient.

\section{Building stone decay pathways}

Different decay patterns visible in the building stone thin sections shown in Fig. 6 can be indicatively linked to the dominance of cementing components. In calcareous TOL, near surface fissures run parallel to faintly visible bedding orientation and through a pronounced crust, resulting in a progressive delamination of the dense fabric. In clay-bearing WT2, dissolution of fabric at a greater depth has resulted in more heterogeneity, with areas of very high porosity reflected in the high measured open porosity and low p-wave propagation of its partner sample WT1 (Table 2). These samples come from buildings dating to a similar era, and although it is unclear precisely what part of the White Tower was sampled, TOL and WT1-3 all come from currently external masonry. However, whilst large areas of the White Tower base were enclosed by later structures for long periods, WT samples were highly exposed in the south facing Wardrobe Tower for several centuries and there is evidence of repair using inappropriate materials. The aspect and contingency of exposure, and past repair programs can be a further factor in the varying emergence and rate of decay.

Several results provide further evidence that variation is amplified in situ as a result historic contingency, micro-environmental and/or baseline mineralogical variation. Gypsum was identified in WT1-3, MRT and HC7. It is likely to have formed from soluble calcite reacting with atmospheric sulphur dioxide. Gypsum is absent in 


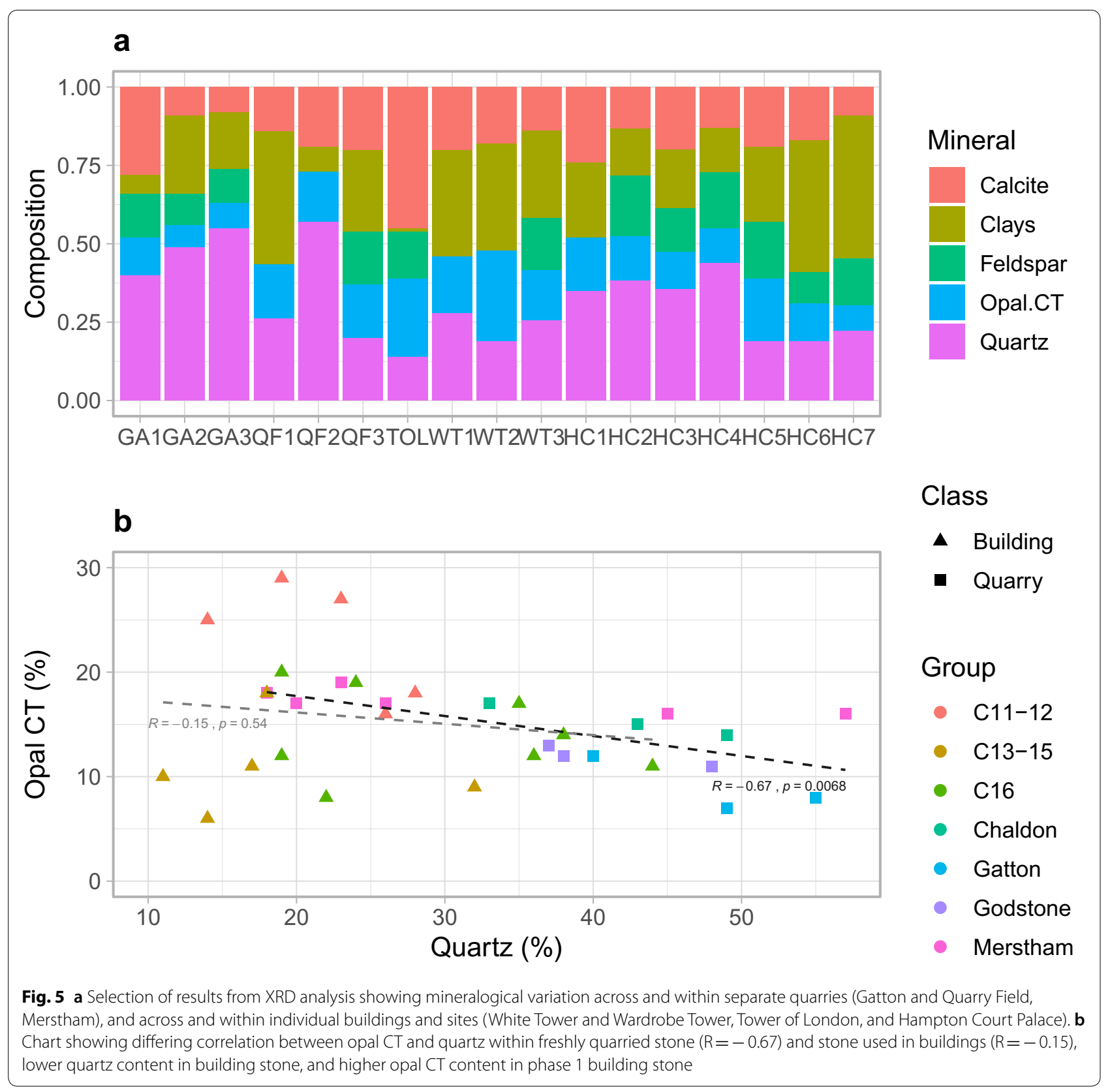

samples HC1-6, which are likely to have been buried before industrial scale coal burning. The different levels present in WT1-3 indicate that variable contamination is possible in highly proximate stones, possibly due to slight petrographic or microclimatic differences. Initial hygric characterisation tests on MRT indicate the effect contamination can have on physical properties: capillary absorption was very low $\left(28.2 \mathrm{~g} / \mathrm{m}^{2} \mathrm{~s}^{0.5}\right)$, presumably as a result of the pore clogging effect of near surface gypsum; sorptivity was very high $(46.2 \%)$, possibly due to the hygroscopicity of other trace salts. After the sample was thoroughly rinsed and retested, results were closer to those of uncontaminated samples (Table 2). The mineralogical variability present in samples from the same building implies that in some cases stone came from a variety of sources. Variability in $\mathrm{HC1}-7$ is as high as any of the measured variability within individual quarries (Fig. 3). Macroscopic inspection of the samples suggests that they are representative of at least two distinct typologies, evident in different colour. Provenance from multiple quarries and/or material recycled from several buildings appears likely. 
(See figure on next page.)

Fig. 6 Photomicrographs of selected thin sections, showing variability of mineralogy, texture and grain size within and across different quarries and buildings, different decay patterns within building stones, and highlighting some common mineral components. GA1 and GA2 taken from same quarry face show high level of petrographic and physical variation, neither is similar in texture to building stone samples. QF3 is more similar to building stone, but shows high porosity with some suggestion of bedding direction. TOL and WT2 show evidence of varying decay phenomena. RS1 shows some of the minerals described in this study

Other results indicate that some degree of homogenisation can result from decay. Whilst there is no significant difference in the average or range of open porosity between quarry samples and building stone samples, it is notable that building stones have a slightly higher open porosity (Fig. 7). This does not reflect the overall correlation between higher bulk density and lower open porosity $(R=-0.57)$ (Table 3$)$. This could partly be due to the dissolution of matrix opening previously closed areas of porous network. The pore-size distribution, which has not been measured here, may be a crucial factor in determining variable durability. Although the primary, opalCT matrix will form a regular porosity in the $10^{2} \mu \mathrm{m}$ region, the clay mineral fraction may result in highly bimodal distributions. This will increase the risk of salt decay mechanisms [75]. The role of calcite as a pore filling cement will play an important role in pore size distribution and open porosity. Weathering of calcite could increase connected, open porosity in near surface areas, especially in case hardened stones.

There is no clear pattern to anisotropy (Table 2). The highest value is in GA2, an example of mature Reigate Stone, with more advanced diagenesis and bio-perturbed bedding; its anisotropy is therefore unlikely to be a consequence of bedding structure. With variation within and across individual quarries high, neither maturity nor paleoenvironment are good indicators of anisotropy. Samples in which bedding direction is visible in thin section, such as QF3 and TOL (Fig. 6), have low anisotropy. The low anisotropy in WT1 is notable given the advanced state of decay of its partner WT2 (Fig. 6). Rather than compounding pre-existing bedding structure, this suggests that decay has had a levelling effect on the internal fabric. The implication of these findings is that Reigate Stone is at most weakly anisotropic. Post-sedimentary processes prior to quarrying and decay processes following construction can override bedding structure.

\section{Synthesis}

\section{Discussion}

The largely nineteenth century differentiation between Firestone and Hearthstone, used to distinguish stones for different purposes as much as of different properties, has led to contemporary discourse describing two distinct typologies of Reigate Stone $[8,19]$. This typically associates Firestone with calcite and Hearthstone with clay.
The reality is that there are likely to be as many different mineralogical compositions as there are intercalated beds in the geological stratum. When defining the macrogeology of the Upper Greensand, Jukes-Brown [12 p. 38 onwards] described zones of deposition defined by space, time and life (i.e. organic sediment). Particularly due to the characteristic species of a thus defined zone, there can be considerable overlap in resulting mineralogy. This is reflected in the findings presented here; compositional variability is present in stones sampled at relative proximity within single quarry faces. Furthermore, the stones used in medieval construction do not conform to a clear typology or necessarily contain increased calcite. Firestone and Hearthstone may be representative of two selectively exploited sub-types; however, when discussing the full history of Reigate Stone used in buildings, it may be more useful to consider a broad mineralogical range. This will not alleviate persistent difficulties in classifying Reigate Stone according to common lithologies such as sandstone or limestone [e.g. 8, 12]. Instead it demands that each use in masonry is assessed individually and conservation strategies are tailored accordingly.

There are nevertheless patterns evident in Reigate Stone selection and use over time. Identifying these has benefited from synthesising documentary research with material analysis, which was only possible on a small sample set due to the restrictions of the historic built environment. The samples investigated here do not reflect the full variability of quarry samples. Whilst they vary in mineralogical composition, density and strength characteristics are more uniform. The earliest building stone investigated here (TOL), sampled from the eleventh century White Tower, supports anecdotal evidence that early use Reigate Stone conformed to a particularly durable variety, which became exhausted during London's rapid growth. Only one quarry sample (GA1) matches the hygro-physical properties of this building stone. As with many of the quarry samples investigated here, its coarse, less homogeneous texture suggests it may not have been a suitable freestone. No quarry face reliably provides stone that is comparable to those sampled from buildings. Large quantities of waste material found in later medieval quarries suggest quarrymen became adept at purposefully selecting stone [19]. It is possible that this was a process of trial and error, and that particularly the Reigate Stone industry boom of the thirteenth 

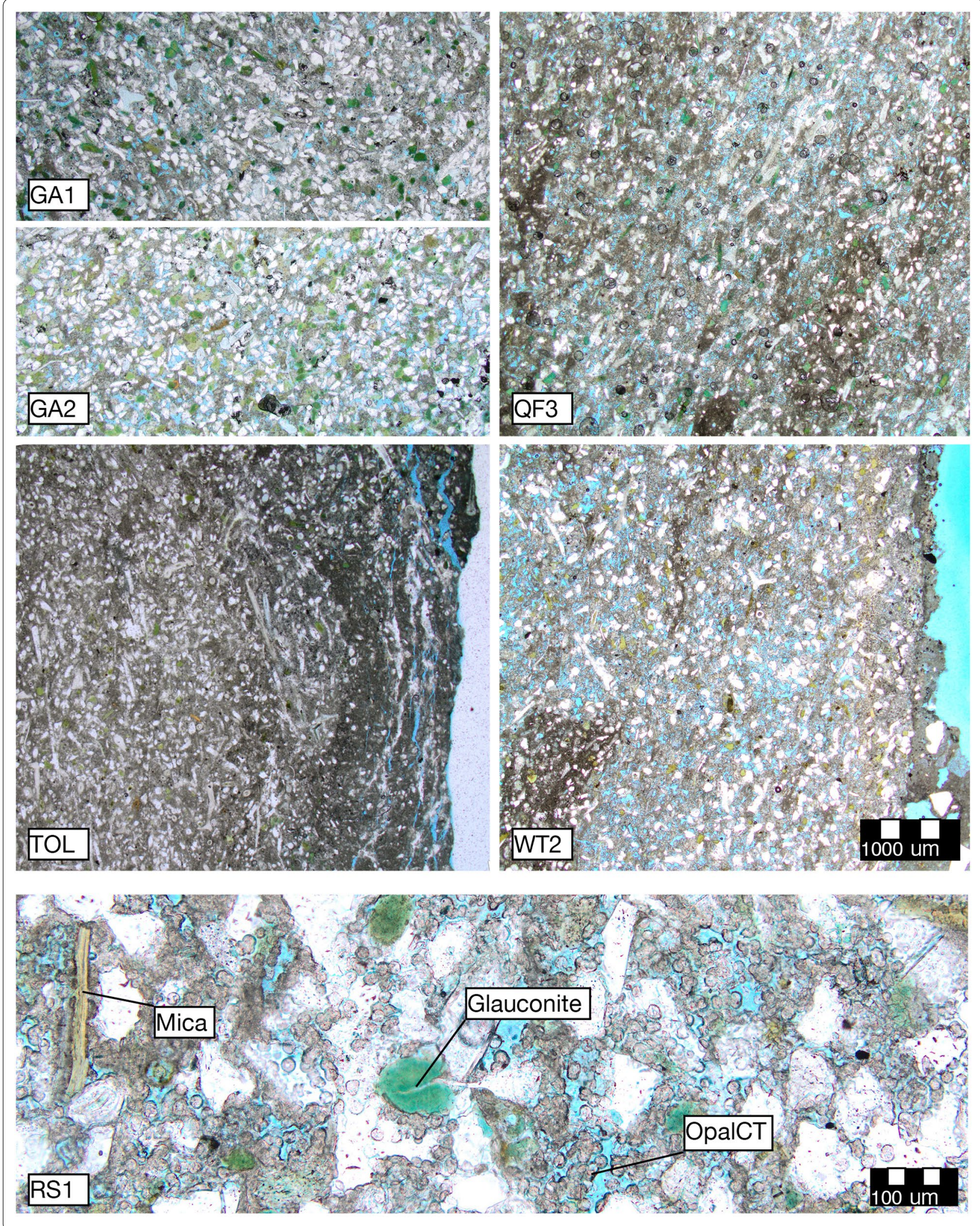


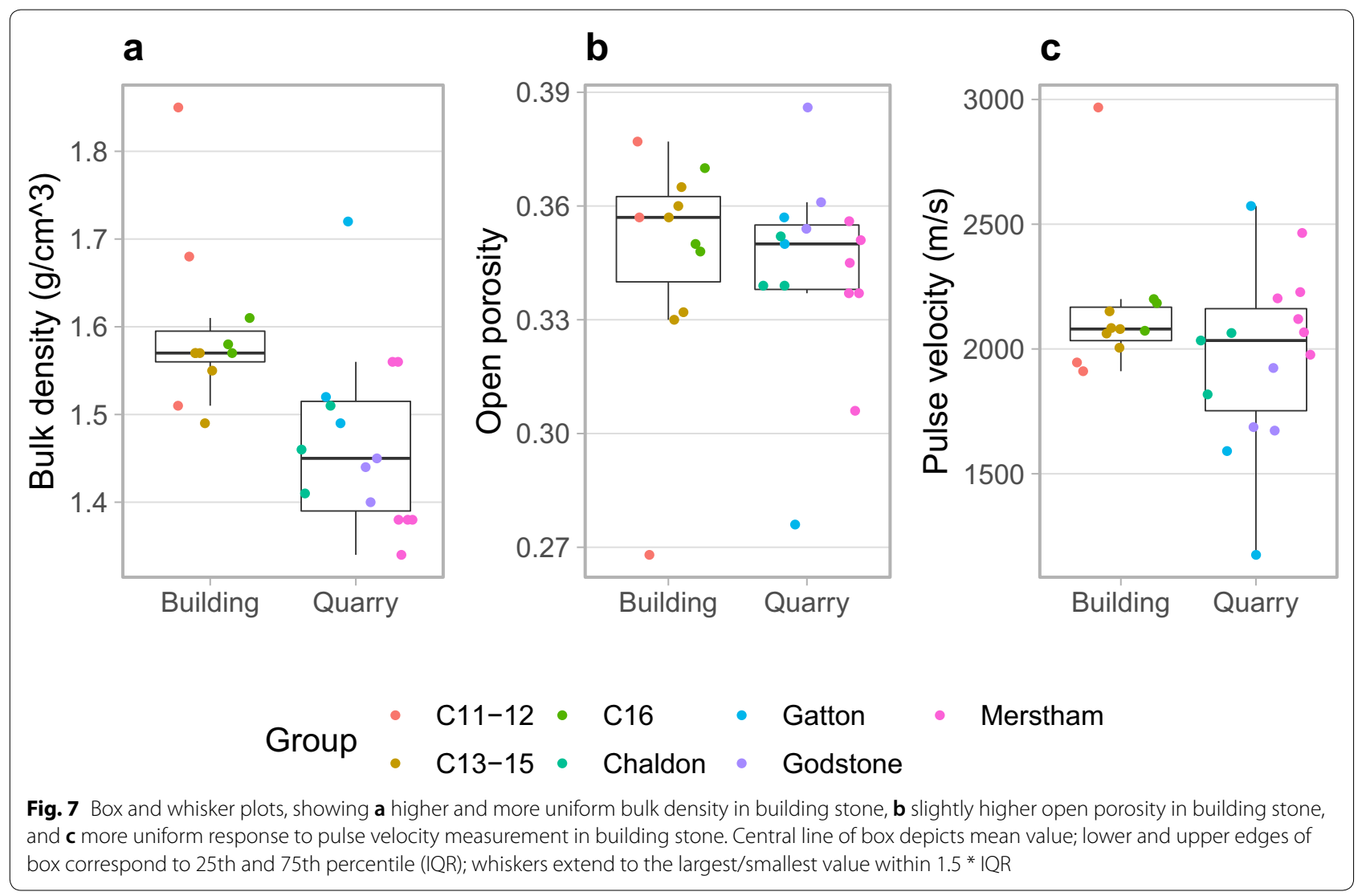

century saw lesser quality material extracted and used in buildings. This is supported by findings presented here, which associate a second phase of Reigate Stone exploitation with increased clay content. This could be a reason for some of the early failings of the stone, which had tarnished its reputation by the fifteenth century. This does not contradict findings made elsewhere, which suggest extant Reigate Stone is more calcareous [8]. Any attempted characterisation of building stone according to extant masonry is however to ignore potentially vast amounts of stone which were being replaced by the thirteenth century. Following centuries of limited, targeted use, which developed a quarrying industry around reliable sources, selection criteria for easily workable stone during the rapid expansion of quarrying activity in the twelfth century are likely to have introduced inferior quality.

Beyond the selection of suitable stone, there is further evidence that workmanship may have influenced the performance of stone in situ. The historical analysis presented here builds on previous assessments of changing use throughout history, to suggest that Reigate Stone economies were well established before the Norman conquest and the stone was a valued resource $[1$, $36,37]$. However, significant growth in demand in the
High Medieval and Early Modern periods is likely to have affected workmanship and logistics. The presence of calcite and its correlation with harder, denser stone suggest that seasoning of freshly cut stone will have been important. Roughly cutting stone to shape before this case hardening will also have greatly improved resilience. Knowledge and mastery of these processes are likely to have refined over time, with templates being sent to quarries and adequate shelter for seasoning being provided perhaps only after initial difficulties became apparent. When Christopher Wren did make use of the stone in later centuries, he demanded great care be taken during storage [20]. Anisotropy does not appear to affect Reigate Stone, however there is some evidence of flaking occurring along bedding planes in samples where these are visible (e.g. TOL). This suggests in some environments incorrect laying of the stone may have accelerated decay. Especially given the poor visibility of bedding planes, errors during construction following lengthy transport and stockpiling are likely to have occurred. In the case of TOL, the stone appears to have been face bedded rather than surface bedded. These factors will have contributed to divergent decay pathways.

This study identifies correlations between different cementing components and hygric mechanisms affecting 


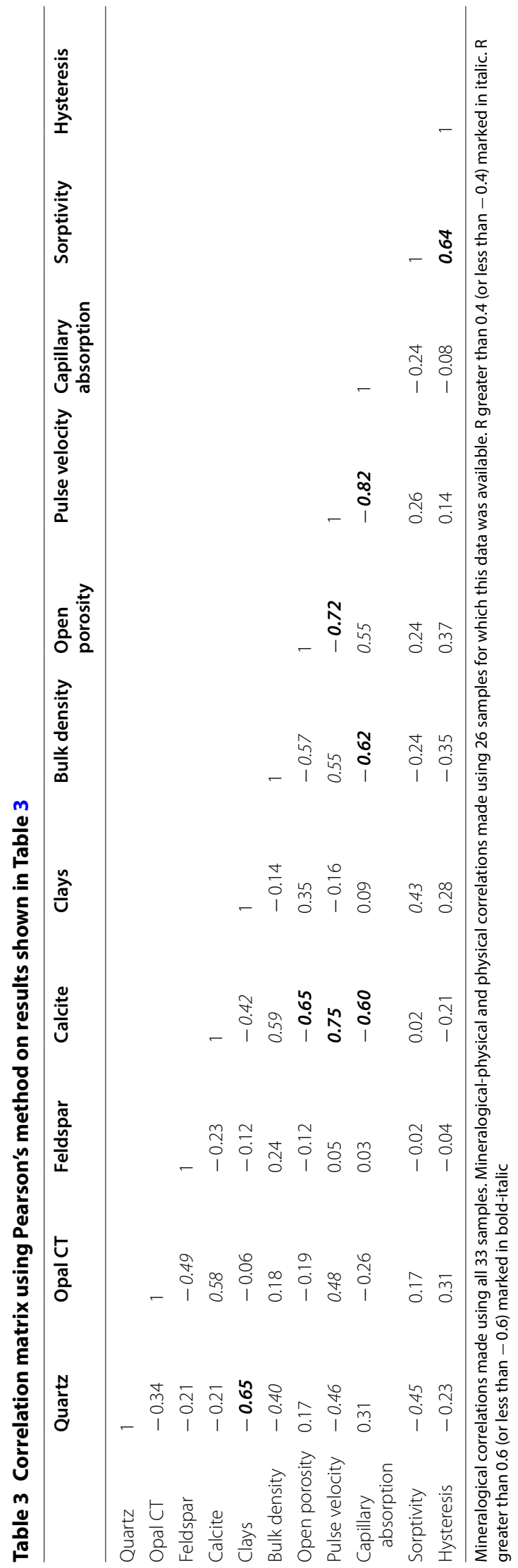




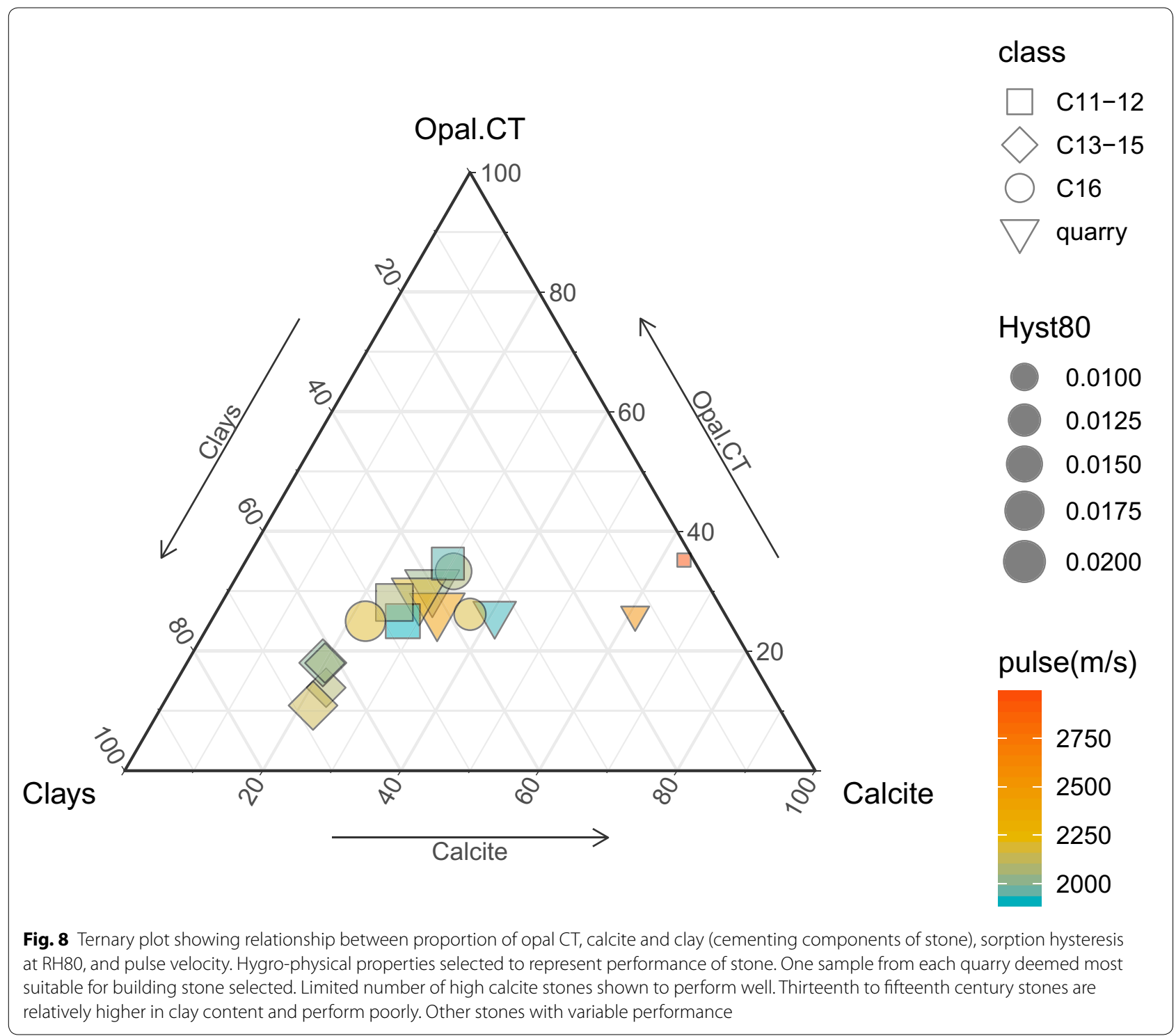

resilience. These underline complex decay processes in relation to the environment, which will be affected by spatial, micro-climatic variations and temporal, macroclimatic changes. Increased calcite content impacts positively on strength characteristics; its pore-clogging properties are shown to reduce capillarity, but water uptake is still rapid in most stones. Coupled with high moisture absorption and retention, particularly in stones with abundant clay minerals, Reigate Stone will be prone to moisture related decay processes and is likely to be highly sensitive to alterations caused by salt contamination. Associated decay phenomena such as gypsum crust formation and spalling have been well documented in other vulnerable historic freestones [2, 3]. Varying calcite and clay contents are likely to preclude standard stone conservation treatments being suitable for all types of Reigate Stone, with targeted selection necessary depending on mineralogical composition. Assessment of past treatments indicate that effective long-term consolidation is only possible in more calcareous, and therefore naturally less vulnerable stones [18].

The cumulative effect of decay and changing approaches to conservation will have increased variability over time. The dynamics of building stone decay are known to be complex and non-linear [16]. Minor physical differences may diverge thresholds at which decay becomes evident. Besides the impact of environmental change upon rates and patterns of decay, the impact of cultural change upon the perception of deterioration has been a significant factor in shaping variation in the 


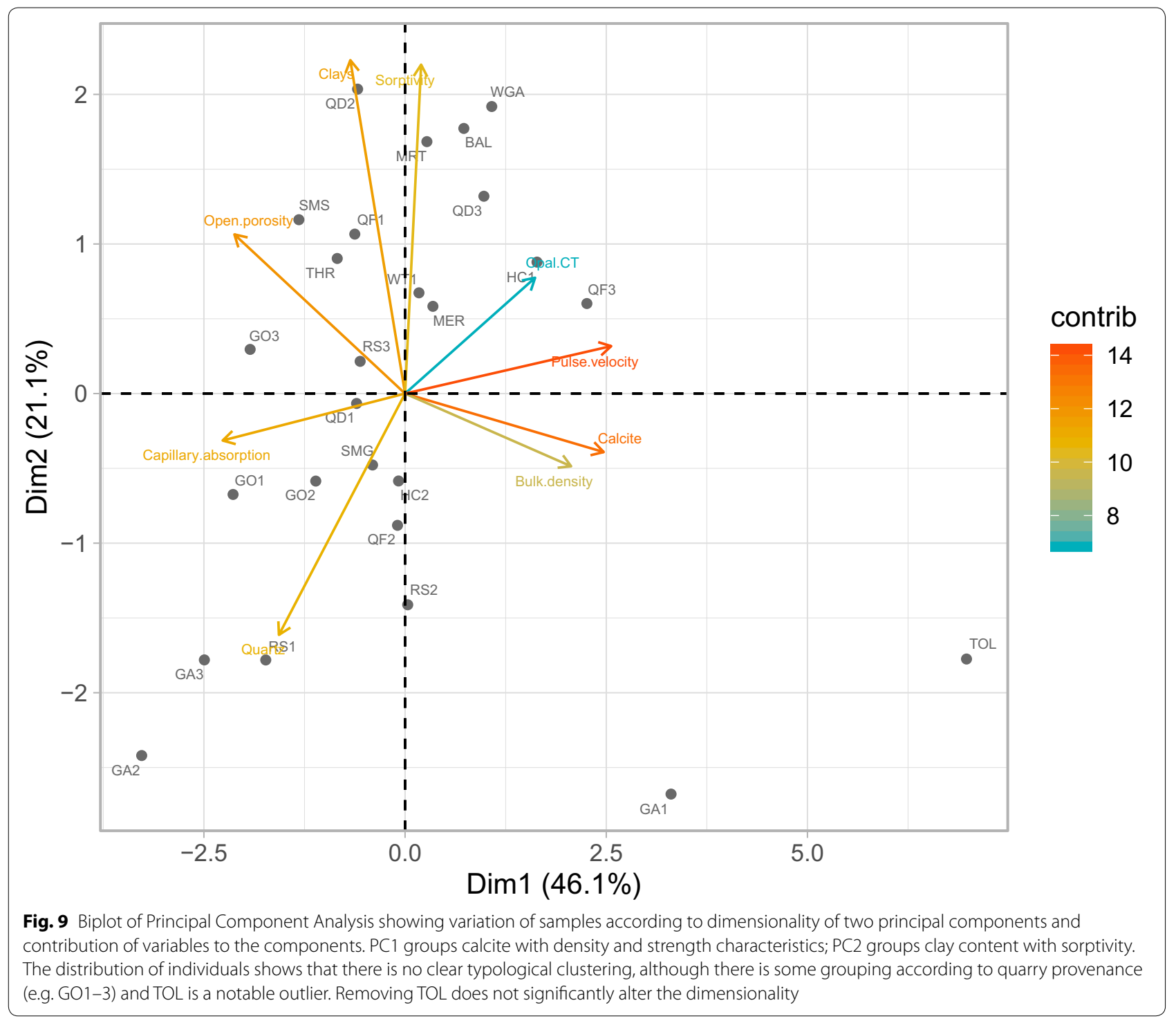

Table 4 Results of PCA, showing contribution of PC1-4 to overall variability, and contribution of individual variables to each PC

\begin{tabular}{lclll}
\hline Variable & PC1 (46\%) & PC2 (21\%) & PC3 (11\%) & PC4 (10\%) \\
\hline Quartz & 9.9 & 23.4 & 4.7 & 3.1 \\
Opal CT & 5.8 & 1 & 33.6 & 28. \\
Calcite & 14.5 & 6.5 & 14.1 & 4.9 \\
Clays & 2.2 & 33 & 7.2 & 1.7 \\
Bulk density & 7.1 & 2.7 & 25.6 & 23 \\
Open porosity & 7.2 & 16 & 5.8 & 0.9 \\
Pulse velocity & 24.5 & 1.4 & 0 & 5.6 \\
Capillary absorption & 19.4 & 2.4 & 2.3 & 7.3 \\
Sorptivity & 9.4 & 13.7 & 6.7 & 25.1 \\
\hline
\end{tabular}




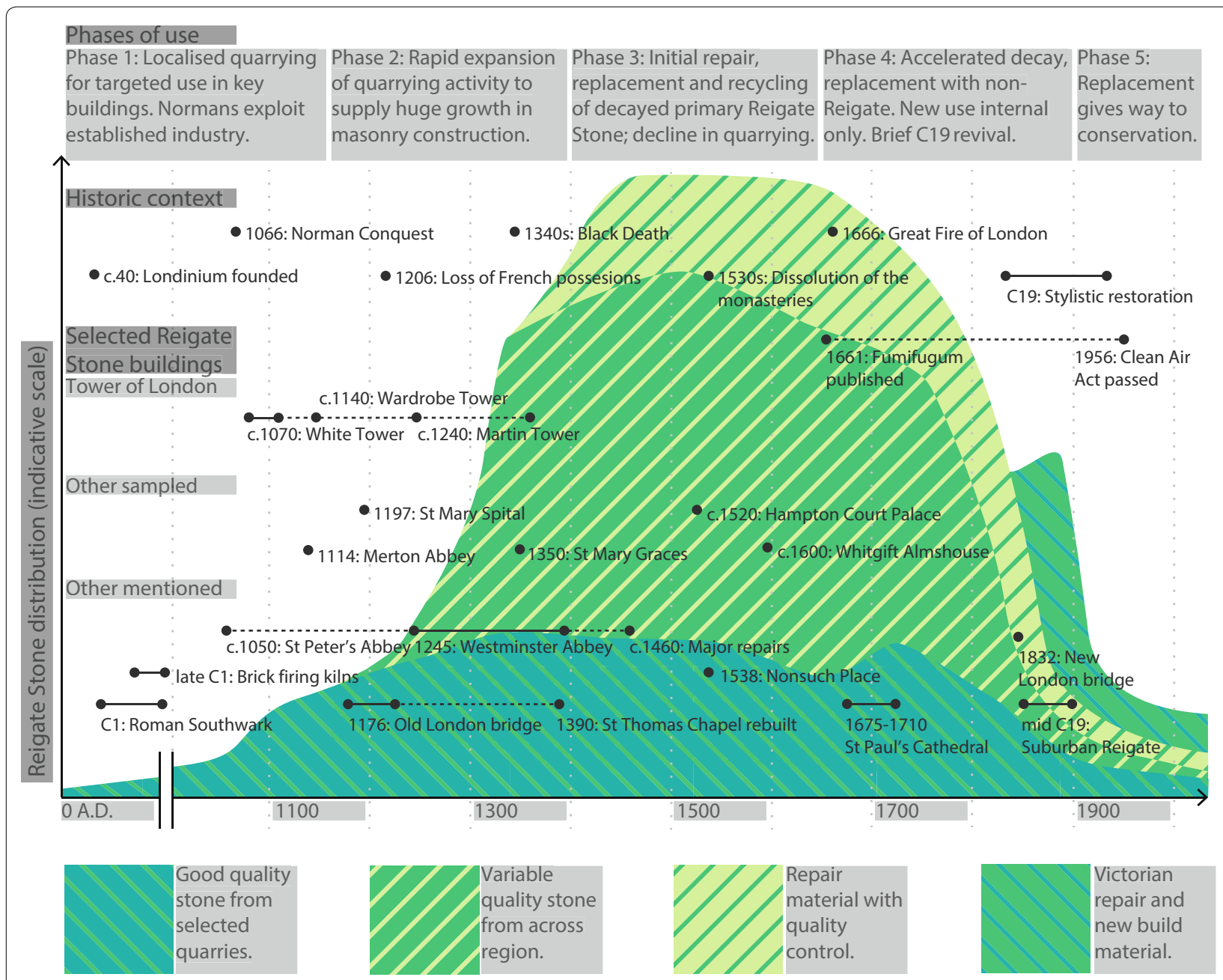

Fig. 10 Hypothetical model of Reigate Stone distribution, distinguishing broadly classified stone types, aligned with timeline of Reigate Stone quarrying and construction, showing different phases of use, and key events and buildings mentioned in this study

historic built environment. Within an overall pattern that has shifted from replacement and renewal to preservation and consolidation over the past two centuries, there has been nuance and disparity in response to socio-economic context. Overlaying these two complex trajectories, nonlinear physical decay and idiosyncratic perception of deterioration, imparts a lack of contingency on conservation strategy; one area of Reigate masonry may cross a decay threshold and be replaced one decade, only for the rest to cross the same threshold yet be treated with a consolidant the following decade. Introducing the new materials of replacement or consolidation, and the memory effect of past environmental stresses, into this already intricate system dynamic serves only to augment the variability of initially minor, physical differences.

\section{Synopsis}

The objectives of this investigation were to establish patterns of use in Reigate Stone exploitation pertaining to variability, define variability in mineralogical terms, and link mineralogical composition to physical characteristics known to influence decay. This was intended to contribute to the overall aim of building a model of the processes which have contributed to variability in historic masonry. This model can be visualised as a timeline, tracking Reigate Stone use in building through several phases (Fig. 10).

1. Early use, prior to and in the first century following the Norman conquest, was limited and targeted. The focus was on detailing and supplementation of other more widely used lithologies such as Kentish Ragstone and Caen Stone. Quarrying was restricted to a 
small number of locations and it was possible to supply durable stone of uniform quality.

2. The second phase of use, from the twelfth to the fifteenth centuries, witnessed huge growth in masonry building and accordingly a significant expansion of quarrying activity. Whether due to inherent variability found in new quarrying locations, or due to the stresses of increased demand leading to a decline in workmanship and quality control, this phase saw the introduction of less resistant stones into the built fabric. Growing logistical complexity may have resulted in masonry with stones of variable provenance or maturity, as stockpiling locations became a necessary juncture between quarry and building site and centralisation streamlined supply.

3. The third phase of use sees a first wave of replacement, repair and refinement in response to the decay of less durable stones, beginning in the fifteenth century following several centuries of weathering activity. Understanding of the limitations is likely to have improved and ongoing use may have been subject to more stringent quality control. However, it is possible that supplies of the best quality Reigate Stone had been exhausted. Compounded by socio-economic factors, which led to reduced demand for freestone, quarrying activity gradually declined. Good quality Reigate Stone was still a valued resource; robbing of disused buildings and reuse in new buildings is likely to have occurred in many cases. This will have further increased the inherent variability found within individual masonry units.

4. The fourth phase brings gradual changes to London's environment, beginning in the seventeenth century and climaxing in the intense pollution of the latenineteenth century, which accelerated the decay of even good quality Reigate Stone. The value of the stone decreases and as the construction industry grows anew, replacement with newly available alternatives becomes more common. Whilst a brief Victorian revival introduced a small amount of fresh Reigate Stone into the historic fabric, the overall stock drastically falls.

5. A final phase beginning in the twentieth century focussed on attempts at conserving and consolidating remaining Reigate masonry. Selective treatment is likely to have further amplified inherent variability.

\section{Conclusion}

This paper has investigated the causes of inherent variability in historic Reigate Stone masonry. The methodological approach has been to synthesise historical analysis of its use with scientific examination of its properties.
This approach has revealed patterns which can be used to build a hypothetical model of processes resulting in variability. Reigate Stone was Medieval London's principal freestone. It was used in vast quantities during a key growth period in London's history. Huge demand may have outstripped the supply of good quality building stone as quarrying adapted from localised supply for specific projects prior to the twelfth century, to industrial exploitation in step with rapid, regional economic growth in the following centuries. This introduced mineralogical variability into the built fabric.

Different mineralogical components are shown here to influence key material properties known to control the onset of decay in building stones. Calcite content influences strength and capillarity. The abundance of clay mineral phases affects adsorption. As the main matrix forming cement, the highly soluble opal-CT content will play an additional role in long-term moisture transport and durability. Whilst the precise interplay of these cementing components and their net effect on the resilience of individual building stones is likely to be complex, small initial differences can result in variable response to environmental processes and the divergence of decay pathways.

In historic buildings, any resulting variation in the onset of decay would have been further augmented in response to changing economic and environmental context. Successive material interventions and recycling of built fabric occurred as a reflection of changing attitudes to architectural heritage and introduced further complexity. Understanding not only the material and environmental factors, but also the historical contingency underlying inherent variability in Reigate Stone masonry is key to the design of ongoing conservation strategies. In terms of practical guidelines, this demands a thorough documentary analysis of past changes to a masonry system, and careful documentation and archiving of any new changes for the benefit of future work.

\section{Abbreviations \\ XRD: X-ray diffraction; $\mathrm{RH}$ : Relative humidity; PCA: Principal component analysis; PC: Principal component; Opal-CT: Opal-cristobalite-tridymite; RS: Rockshaw Lodge; QD: Quarry Dean; GA: Gatton; GO: Godstone; QF: Quarry Field; TOL: (White Tower) Tower of London; WT: Wardrobe Tower; BAL: Balium Wall; MRT: Martin Tower; MER: Merton Priory; SMS: St Mary Spital; SMG: St Mary Graces; THR: Throwley Church; HC: Hampton Court Palace; WGA: Whitgift Almshouses.}

\section{Acknowledgements}

The authors would like to thank Hong Zhang, Owen Green and Katherine Clayton from the University of Oxford for technical and analytical support with the petrographic experiments; Peter Burgess and his colleagues from the Wealden Cave and Mine Society for facilitating a tour of the Reigate mines and providing useful historical information; Robin Sanderson and Keith Garner for making available an extensive sample collection and unpublished data from their previous research; Xiaoke Liu from University College London for help with the statistical analysis; colleagues from HRP for support and guidance, in 
particular Jo Thwaites and William Page for locating and providing additional samples; and three anonymous reviewers for valuable feedback.

\section{Authors' contributions}

MM contributed to all stages of work. HV, CV and IA contributed to the conception of the work. HV additionally contributed to the design of the work. All authors read and approved the final manuscript.

\section{Funding}

This work was supported by funding from the Engineering and Physical Sciences Research Council (EPSRC) and Historic Royal Palaces (HRP) as a part of the Centre for Doctoral Training in Science and Engineering in Arts, Heritage and Archaeology (SEAHA) (Grant Number: EP/L016036/1).

\section{Availability of data and materials}

The datasets used and/or analysed during the current study are available from the corresponding author on reasonable request.

\section{Competing interests}

The authors declare that they have no competing interests.

\section{Author details}

${ }^{1}$ School of Geography and the Environment, University of Oxford, Oxford, UK. ${ }^{2}$ Historic Royal Palaces, London, UK. ${ }^{3}$ Carden \& Godfrey Architects, London, UK.

Received: 27 March 2020 Accepted: 25 July 2020

Published online: 08 August 2020

\section{References}

1. Tatton-Brown T. The quarrying and distribution of Reigate Stone in the middle ages. Med Archaeol. 2001;45(1):189-201.

2. Beck K, Al-Mukhtar M. Weathering effects in an urban environment: a case study of tuffeau, a French porous limestone. Geol Soc Lond Spec Publ. 2010;331(1):103-11.

3. Dewanckele J, Boone MA, De Kock T, De Boever W, Brabant L, Boone MN, Fronteau G, Dils J, Van Hoorebeke L, Jacobs P, Cnudde V. Holistic approach of pre-existing flaws on the decay of two limestones. Sci Total Environ. 2013;447:403-14

4. Přikryl R, Přikrylová J, Racek M, Weishauptová Z, Kreislová K. Decay mechanism of indoor porous opuka stone: a case study from the main altar located in the St Vitus Cathedral, Prague (Czech Republic). Environ Earth Sci. 2017;76(7):290.

5. Odgers D. Learning from the past: a review of treatments carried out to Clunch in 1985. J Architect Conserv. 2013;19(1):3-17.

6. Gomez-Heras M, Smith BJ, Viles HA. Oxford stone revisited: causes and consequences of diversity in building limestone used in the historic centre of Oxford, England. Geol Soc Lond Spec Publ. 2010;333(1):101-10.

7. Lockwood S. Reigate stone: geology, use and repair. Struct Survey. 1994;12:18-22.

8. Sanderson R, Garner K. Conservation of Reigate stone at Hampton Court Palace and HM Tower of London. J Architect Conserv. 2001;7(3):7-23.

9. Tucker ME. Sedimentary rocks in the field. Hoboken: Wiley; 2003.

10. Schaffer RJ. The weathering of natural building stones. Abingdon: Routledge; 2016.

11. Howe E, Lakin D. Roman and medieval Cripplegate, City of London: Archaeological Excavations, 1992-1998. Museum of London Archaeology Svc; 2004.

12. Jukes-Browne AJ. The cretaceous rocks of Britain: the gault and upper greensand of England. Richmond: HM Stationery Office; 1900

13. Burgess P. Surrey's Ancient stone mines. P. Burgess; 2008.

14. Odgers D, Henry A, Martin B, Wood C. Practical building conservation: stone by English heritage. Farnham: Ashgate Publishing Limited; 2012

15. Fort R, Varas MJ, de Alvarez Buergo M, Martin-Freire D. Determination of anisotropy to enhance the durability of natural stone. J Geophys Eng. 2011;8(3):S132-44.

16. Viles HA, Turkington AV. Can stone decay be chaotic? Spec Papers Geol Soc Am. 2005:390:11.
17. McCabe S, Smith BJ, Warke PA. A legacy of mistreatment: conceptualizing the decay of medieval sandstones in NE Ireland. Geol Soc Lond Spec Publ. 2010:333(1):87-100.

18. Michette M, Viles H, Vlachou-Mogire C, Angus I. Assessing the long-term success of reigate stone conservation at Hampton Court Palace and the Tower of London. Stud Conserv. 2020;22:1-8.

19. Sowan PW. Firestone and hearthstone mines in the upper greensand of east Surrey. Proc Geol Assoc. 1975;86(4):571-91.

20. Hatton M. The exploitation, distribution and use in buildings of Reigate stone. (MA, Birkbeck College 2001). https://www.croydoncavingclub.org. uk/node/380. Accessed June 2020.

21. Owen HG. The stratigraphy of the gault and upper greensand of the Weald. Proc Geol Assoc. 1975;86(4):475-98.

22. Dean WE. The relationship between sea-level changes, facies changes and ammonite distributions in the Aptian-Albian of the Anglo-Paris Basin (Doctoral dissertation, University of London 1994).

23. Dines HG, Edmunds FH. The geology of the country around Reigate and Dorking. Richmond: HM Stationery Office; 1933.

24. Watson J. British and foreign building stones: a descriptive catalogue of the specimens in the Sedgwick Museum, Cambridge. Cambridge: University Press; 1911

25. Shore BC. Stones of Britain: a pictorial guide to those in charge of valuable buildings. In: Hill L. 1957.

26. Lott G, Cameron D. The building stones of South East England: mineralogy and provenance. 2005.

27. Potter JF. Field meeting report: the geology of some West London Churches, 22nd September 2012. Proc Geol Assoc. 2013;124(6):1011-9.

28. Grainger I, Phillpotts C. The Cistercian abbey of St Mary Graces, East Smithfield. London: Mus Lond Archaeol; 2011.

29. Thomas C, Sloane B, Phillpotts C. Excavations at the priory and hospital of St Mary Spital, London. MoLAS Monograph 1, London: Museum of London Archaeology Service; 1997.

30. De Domingo C. The provenance of some building stones in St. Mary Spital by geological methods. Lond Archaeol. 1994;7(9):240.

31. Burnham B, Keppie L, Hassall M, Tomlin R. Roman Britain in 1994. Britannia. 1994;26:325-90.

32. Drummond-Murray J, Thompson P, Cowan C, Burnell S. Settlement in Roman Southwark: Archaeological Excavations (1991-1998) for the London Underground Limited Jubilee Line Extension Project. Museum of London Archaeology Svc; 2002.

33. Mackinder A. A Romano-British Cemetery on Watling Street: Excavations at 165 Great Dover Street, Southwark. London: Museum of London Archaeology Service; 2000.

34. Williams JH. Roman building-materials in south-east England. Britannia. 1971;2:166-95

35. Gower G. On a Roman Villa discovered at Titsey. Surrey Archaeol Collect. 1869:4:214.

36. Coombe P, Henig M, Grew F, Hayward KM, Blagg TF. Roman sculpture from London and the South-East. Oxford: Oxford University Press; 2015.

37. Jones P. A Roman Tile Kiln discovered in Reigate. Surrey Archaeol Soc. 2004

38. Brigham T, Woodger A. Roman and medieval townhouses on the London waterfront: excavations at Governor's House, City of London. London: Museum of London Archaeology Svc; 2001.

39. Johnston PM. Stoke D'Abernon church. Surrey Archaeol Collect. 1907;20:1-89.

40. Jope EM. The Saxon building-stone industry in southern and midland England. Med Archaeol. 1964;8(1):91-118.

41. Tanner LE, Clapham AW. XI-recent discoveries in the nave of Westminster Abbey. Archaeologia. 1933;83:227-36.

42. Huggins PJ, Bascombe KN, Huggins RM. Excavations at Waltham Abbey, Essex, 1985-1991: three pre-conquest churches and norman evidence. Archaeol J. 1992;149(1):282-343.

43. Impey E, Ashbee J, editors. The White Tower. Yale University Press; 2008.

44. Fagg CC. The mineral and agricultural industries of the regional survey area considered geographically. Proc Croydon Nat Hist Sci Soc 1914;7(5):161-74

45. Royal Commission on Historical Monuments (England). An Inventory of the Historical Monuments in London. HM Stationery Office; 1924-1930 (5 Volumes). 
46. Schofield J, Allen P, Taylor C. Medieval buildings and property development in the area of Cheapside. Trans Lond Middlesex Archaeol Soc. 1990;41:39-238.

47. Thomas C. The archaeology of medieval London. Stroud: Sutton; 2002

48. Thomas C, Cowie R, Sidell J. The Royal Palace, Abbey and Town of Westminster on Thorney Island: Archaeological Excavations (1991-1998) for the London Underground Limited Jubilee Line Extension Project. Museum of London Archaeology Svc; 2006.

49. Rackham RB. The nave of Westminster. British Academy. 1909.

50. Public Record Office. Close Rolls of the Reign of Henry III preserved in the Public Record Office. London: HMSO. 1902 (14 Volumes).

51. Salzman LF. Building in England, Down to 1540: A Documentary History. Clarendon Press; 1952

52. Colvin H, editor. The history of the king's works. HM Stationery Office; 1963.

53. Robinson E, Worssam B. The geology of some Middlesex churches. Proc Geol Assoc. 1989;100(4):595-603.

54. Knoop D, Jones GP. The English medieval quarry. Econ Hist Rev. 1938;9(1):17-37.

55. Jackson P. London Bridge. London: Cassell; 1971.

56. Dimes FG, Ashurst J. Conservation of building and decorative stone. Abingdon: Routledge; 2007.

57. Lilley KD. Urban planning after the Black Death: townscape transformation in later medieval England (1350-1530). Urban Hist. 2015;42(1):22-42.

58. Campbell JW. The supply of stone for the rebuilding of St Paul's Cathedral 1675-1710. Construct Hist. 2013:23-49.

59. Schofield J. St Paul's Cathedral: archaeology and history. Havertown: Oxbow Books Limited; 2016.

60. Brimblecombe P, Grossi CM. Millennium-long damage to building materials in London. Sci Total Environ. 2009;407(4):1354-61.

61. Inglesby R. 'Let us Sin with Salvin': architecture and Authority at the Tower of London, 1896-1905. Architect Hist. 2017;60:243-75.

62. EN B. 772-4, 1998, Methods of test for masonry units. Determination of Real and bulk density and of total and open porosity for natural stone masonry units. European Committee for Standardization, Brussels.

63. Benavente D, Martınez-Martınez J, Jáuregui P, Rodrıguez MA, del Cura MG. Assessment of the strength of building rocks using signal processing procedures. Construct Build Mater. 2006;20(8):562-8.
64. BS EN 14579.2004 Natural stone test methods. Determination of sound speed propagation. Brussels: European Committee for Standardization; 2005.

65. Birch F. The velocity of compressional waves in rocks to 10 kilobars: 1. J Geophys Res. 1960;65(4):1083-102.

66. BS EN 1925:1999. Natural stone test methods. Determination of water absorption coefficient by capillarity. Brussels: European Committee for Standardization; 1999

67. Snyder RL, Bish DL. Quantitative analysis. Rev Miner. 1989;101:20.

68. Flörke OW, Hollmann R, Von Rad U, Rösch H. Intergrowth and twinning in opal-CT lepispheres. Contrib Miner Pet. 1976;58(3):235-42.

69. Tresise GR. Aspects of the lithology of the Wessex Upper Greensand. Proc Geol Assoc. 1960;71(3):316-39.

70. Thompson GR, Hower J. The mineralogy of glauconite. Clays Clay Miner 1975;23(4):289-300.

71. Odin GS, Matter A. De glauconiarum origine. Sedimentology. 1981;28(5):611-41.

72. Jolliffe IT, Cadima J. Principal component analysis: a review and recent developments. Philos Trans R Soc A Math Phys Eng Sci. 2016:374(2065):20150202.

73. Stück H, Plagge R, Siegesmund S. Numerical modeling of moisture transport in sandstone: the influence of pore space, fabric and clay content. Environ Earth Sci. 2013;69(4):1161-87.

74. Franzen C, Mirwald PW. Moisture content of natural stone: static and dynamic equilibrium with atmospheric humidity. Environ Geol. 2004;46(3-4):391-401.

75. Benavente D, Martínez-Martínez J, Cueto N, García-del-Cura MA. Salt weathering in dual-porosity building dolostones. Eng Geol. 2007;94(3-4):215-26.

\section{Publisher's Note}

Springer Nature remains neutral with regard to jurisdictional claims in published maps and institutional affiliations.

\section{Submit your manuscript to a SpringerOpen ${ }^{\circ}$ journal and benefit from:}

- Convenient online submission

- Rigorous peer review

- Open access: articles freely available online

- High visibility within the field

- Retaining the copyright to your article

Submit your next manuscript at springeropen.com 